\title{
PROCEDIMIENTOS RETÓRICOS DE LA POESÍA POSMODERNA ESPAÑOLA
}

\author{
Vicente VIVES PÉREZ \\ I. E. S. La Nía (Aspe) \\ vicentefcovives@yahoo.es
}

lo largo de este artículo abordamos el estudio de unas estrategias retóricas
que, a nuestro juicio, configuran la base expresiva de la poética posmoderna
española, retórica común al conjunto heterogéneo de los discursos que forman la denominada generación poética del $68^{1}$. Se trata de una serie de procedimientos cuyas peculiaridades expresivas concitan un uso renovador del lenguaje poético, y que encuentran en el predominio formal su razón de ser: Se trata de la metapoesía, la indeterminación, la kenofilia poética y la resemantización del tópico muerte, elementos retóricos arraigados en el sesentayochismo y que, pese a la pluralidad estética con que éstos se manifestaron en sus tendencias dominantes, e incluso en cada poeta, forman el sustrato expresivo de esta generación. Sin embargo, esta consciente vocación retórica que caracteriza a la poesía posmoderna, que entre los poetas del 68 alcanza un lugar preferente, no irrumpe repentinamente en ellos, pues el marcado artificio formal de su escritura poética se sostiene (y culmina) sobre un proceso previo de experimentación verbal que sobrepasa los márgenes generacionales, ya que se nutre de las diversas aportaciones de los movimientos minoritarios existentes en nuestra poesía ya desde la posguerra (Postismo, Cántico, surrealismo existencial, etc.). En este sentido, algunos estudios críticos recientes han señalado que el formalismo identificado con la renovación lírica que lleva a cabo la generación del 68 no le corresponde con exclusividad, aunque la totalidad de su actividad literaria bien podría ubicarse bajo tales parámetros. En otras palabras, las peculiaridades retóricas y temáticas que caracterizan la poética general del 68 en su origen no carecieron de precedentes inmediatos. En tal

\footnotetext{
${ }^{1}$ Para esta denominación generacional, véase Prieto de Paula (1996) y Lanz Rivera (1994) y (2000).
} 
sentido, vistas desde un amplio contexto histórico-literario, sus propuestas no fueron tan excepcionales ni tan rupturistas, como pretendió la crítica coetánea que las enjuició.

\section{Introducción: el alejamiento del realismo (o la autosuficiencia del signo poético)}

Esta consciente voluntad de renovación del lenguaje, además de adobar el particular esteticismo de los primeros libros de la promoción sesentayochista, incidió en un proceso de recuperaciones de poéticas marginadas (o minusvaloradas) en el panorama literario de posguerra: el acercamiento estético del 68 al intimismo culturalista, el neobarroquismo o el surrealismo suponía un alejamiento del socialrealismo y una justificación retrospectiva respecto de unos antecedentes con los que emparentaba formalmente su escritura. Incluso su rechazo del realismo tampoco fue exclusivo, pues las primeras discrepancias con la estética social ya fueron manifestadas por ciertos autores jóvenes de los 50. A este respecto, se ha observado que, a los postulados realistas desarrollados por las dos primeras generaciones de posguerra en sus distintas versiones (existencialista, social u objetivista), fue aflorando en la década del cincuenta una poesía paralela que, dentro de la generación emergente, se alejaba expresivamente de la corriente social predominante, de modo que la relación que los poetas del medio siglo tienen con el realismo no fue homogénea: mientras en unos es muy estrecha, al extremo de que se les puede considerar «sociales», en otros, orientados a la pesquisa epistemológica o a la experimentación lingüística, es prácticamente inexistente; e incluso, en un mismo autor, el realismo puede presentar discontinuidades y notables cambios de intensidad en la sucesión de sus libros. En suma, la actividad creativa de éstos, si bien pertenecen a la segunda generación de posguerra, no puede incardinarse sin más matices en un realismo aglutinante ${ }^{2}$.

Del grupo de poetas del medio siglo partirían dos líneas fundamentales que marcan las desavenencias con esa estética social, según sea el modo que éstos tengan de relacionarse con la realidad y su opción por un determinado lenguaje: de un lado, están quienes expresan una conciencia crítica de la realidad, sin dejarse absorber por ella, recurriendo a procedimientos varios -el guiño irónico, la viñeta subjetiva histórica y culturalista, la ambigüedad o las citas manipuladas-, y, de otro, aquéllos que se sienten conmocionados ante una realidad que es escrutada por el lenguaje y aparece nuevamente conformada en la escritura ${ }^{3}$. Más que asumir inconscientemente los esquemas verbales con el lenguaje construye la realidad, ambos modos poéticos conciben el poema como un resultado cognoscitivo que ilumina el mundo y la vida, conocimiento crítico que procede de su experiencia misma con las palabras y la

\footnotetext{
${ }^{2}$ Cfr. Prieto de Paula (1996: 16).

${ }^{3}$ Cfr. Prieto de Paula (1993: 40-41).
} 
escritura. La atención preferencial a los elementos formales irá consolidando, pues, una serie de expectativas favorables a un tipo de poesía surgida de la indagación acerca de una realidad que va más allá de lo meramente testimonial y deja de abastecerse de una temática de urgencia histórica. La experiencia ética y estética que los poetas del medio siglo tienen del mundo queda incorporada al poema no tanto por su referencia directa, sino desde una elaboración lingüística previa que requiere una distancia crítica adecuada de la materia verbal usada.

De esta manera, los autores de los 50 son ya conscientes de que la irreductibilidad de la realidad al lenguaje cotidiano y sencillo constituye, paradójicamente, una irrealidad, y desconfían de la capacidad de dicho lenguaje para referirla. En consecuencia, el poema se convierte en una vía de indagación a través de la reflexión verbal que supone su creación. Tanto el trabajo formal de la escritura del poema como la reconstrucción de la memoria personal desde la ficcionalización poética propician la superación estética del realismo que daba, ya a finales de esa década, síntomas inequívocos de agotamiento. Éste resultaba particularmente evidente en lo referido a la intención ideológica de una concienciación colectiva manifestada con una retórica que, en aras de una recalcitrante claridad, estaba al servicio de una función representativa que no colmaba las expectativas de lo poético. Y es que la poesía social acabó mostrando, en sus derivaciones últimas, un paradójico proceso de desrealización, por cuanto la realidad a que aludían los poemas respondía a un esquema de representación idealizado, resultado de un lenguaje cotidiano que era inocuo críticamente ${ }^{4}$. A partir de entonces, se fue imponiendo una experimentación verbal que tendía a expresar -y también a reconocer- la incomodidad de las relaciones convencionales entre la palabra y el mundo 5 .

En este contexto impregnado por la reflexión crítica acerca de la naturaleza del lenguaje y la imposibilidad de su objetivismo referencial, la poesía del 68 marca una distancia más radical que la generación anterior respecto de la estabilidad epistemológica del lenguaje, al cuestionarlo como vehículo por el cual se genera y transmite la realidad. En su conjunto, la escritura de estos poetas representa una manifestación crítica producida por la ruptura definitiva entre sujeto y lenguaje, entre poema y mundo. La poesía sesentayochista se aplica a descalificar el mecanismo referencial y representativo del signo, mediante el cual la razón impone su orden sobre el pensamiento. Al poner en entredicho el esquema racional y las estructuras que permiten organizarlo sistemáticamente, la poética posmoderna española incide en un descubrimiento crítico de los procedimientos represivos y de dominación que el uso

\footnotetext{
${ }^{4}$ Cfr. Lanz Rivera (2000: 356, 363-364).

${ }^{5}$ Cfr. García Jambrina (1992: 8).
} 
instrumental del lenguaje produce; no en vano, la literatura posmoderna se postula como respuesta transgresora al canon estético de la modernidad, pues establece una hibridación de sus materiales culturales con el fin de perturbar los modelos cultos de la tradición. A la poesía del 68 corresponde descubrir y superar muchas de las obsolescencias de la poética moderna y cancelar paródicamente sus modelos estéticos más representativos (Simbolismo y Realismo), mediante una actitud displicente y relativizadora de absolutos. Así, la primacía formal y el artificio poético no aparecen sólo en la poesía del 68 como motores específicos de la superación de la estética social anterior, sino que se destinan también a cuestionar críticamente los modelos artísticos de la tradición.

Testigos del desmoronamiento del humanismo clásico y partícipes de la remodelación irónica de los tópicos del arte occidental, los poetas de esta generación plantean en sus discursos poéticos una total desacralización de los componentes tradicionales del arte. Este rechazo se conecta con un fuerte sentido crítico hacia los modos de transmisión ideológica que representan los modelos artísticos convencionales en el nuevo marco de una cultura posmoderna. El predominio formal de la obra pretende desestabilizar los principios de la comunicación poética tradicional, una vez cuestionada la correspondencia entre el lenguaje y el mundo. El poema acoge a menudo una reflexión crítica sobre la necesidad de superar la expresión directa propia del dictum romántico, y de rechazar la sumisión del signo poético a los valores instrumentales del lenguaje. De ahí que esta promoción considere que la naturaleza estética del poema depende sólo del uso que el poeta haga de la lengua. Una vez asumido que su escritura ni servía para cambiar el entorno social y político, ni podía configurarse como expresión directa de un mensaje ideológico explícito, la función estética se convierte en el eje primordial de la composición. Frente al valor comunicativo de la poesía social y su intención rehumanizadora, los autores del 68 hacen recaer en la función estética la labor específica de poner en cuestión el lenguaje mismo. Con ello se pretende criticar el sistema y el código que afirma al poder.

La poesía del 68 asume de manera general una renovación de lo poético a través de la crítica del lenguaje y desdeña las fórmulas retóricas escleróticas de la poética social. Tratan de superar así el academicismo ideológico en que había caído el realismo, liberando al lenguaje de su subsidiariedad respecto al mensaje. Denominada significativamente «generación del lenguaje» ${ }^{6}$, la tarea literaria de los poetas del 68 se sustenta en una supremacía de lo verbal que reclama para sí un protagonismo cuya finalidad consiste en devolver al signo lingüístico su dignidad estética. Desligada de sus atribuciones tradicionales, la poesía deja de ajustarse a una finalidad de concienciación

\footnotetext{
${ }^{6}$ Cfr. De Cuenca (1979-1980: 245-251).
} 
social, de salvación o de catarsis personal: será un ejercicio de estilo, y sus valores artístico y crítico se justifican en el efecto retórico de sus componentes ${ }^{7}$. Al tener en cuenta la importancia de esta naturaleza retórica del discurso por encima de temas y de contenidos, estos poetas actualizaban la tesis de McLuhan -como advertía Castellet para los novísimos- de que la forma del mensaje es su contenido. La formalización lingüística de un asunto se convierte en el tema mismo del poema, y, sensu contrario, todo contenido se ciñe a su forma. Al explotar la expresividad de sus componentes verbales, «el texto se elevaba como una creación con existencia autónoma, el objeto artístico se constituía en referente de sí mismo y, por lo tanto, carecía del carácter mimético de la creación "realista". La negación del contenido implicaba negar cualquier posibilidad interpretativa del poema con respecto a la realidad» (Lanz Rivera, 2000: 444). Constituido en su propio referente, el lenguaje poético acota sus posibilidades de remitir a un espacio extralingüístico. El poema se recluye en una autoconciencia, el lenguaje se ensimisma al romperse su biunivocidad respecto del mundo, y la opacidad resultante de ello conduce al predominio de la forma. En otras palabras, el efecto poético se produce a partir de una construcción verbal cuya consciencia de artificio se sostiene sobre una compleja estructuración textual en diferentes niveles de significación. El poema articula su escritura como un juego interpretativo de reconstrucciones hermenéuticas abiertas en las que queda implicado el lector. Estos poetas «volvieron a restablecer en el empeño formal de su escritura la antigua relación existente entre gramática, retórica y poética así como una moral o ética del lenguaje» (Siles, 1989: 9). En suma, la poética posmoderna española adquiere una sutil dimensión epistemológica originada en una particular comprensión discursiva del mundo y de la realidad, donde «l'unique vérité est celle du texte» (Zimmermann, 1983: 17).

Más allá de una simple noción de desvío estilístico, y acogida bajo la autosuficiencia del signo poético, la escritura de estos poetas entra en conflicto con la inmediatez de una referencialidad presente en la palabra. No extraña que una actitud común en el conjunto de sus poéticas sea la distancia irónica que el texto marca respecto a las modalidades de una representación, al servirse de mediaciones simbólicas procedentes de la tradición y de la historia del arte. Desde esta perspectiva, la significación del poema vertebra referencias y sentidos extraídos de ámbitos culturales diversos, incluida la propia disciplina lingüística, de manera que éstos constituyen esa realidad de «segundo grado» sobre la que se asienta el lenguaje del poema. En

\footnotetext{
${ }^{7} \mathrm{Al}$ respecto, puede leerse la siguiente reflexión en G. Carnero: «poetizar es ante todo un problema de estilo. Un estilo efectivo da carta de naturaleza a cualquier motivo sobre el que se ejercite. La recíproca es una barbaridad; no hay ningún asunto, ninguna idea, ninguna razón de orden superior, ningún sentido respetable (quedan poquísimos), ningún catálogo de palabras nobles, ninguna filosofía (aunque esté cargada de futuro) que por el hecho de estar presentes en un escrito lo justifiquen desde el punto de vista del Arte» (apud Provencio, ed., 1988: II, 177).
} 
consecuencia, la renovación lírica de los autores del 68 conlleva un formalismo erigido sobre las ruinas del lenguaje cotidiano y el uso convencional de sus significados. Esta conciencia de escribir desde las ruinas del lenguaje implica una escritura como un estricto ejercicio de textualidad en el que sólo importan las destrezas técnicas y el manejo manierista de los tópicos culturales. El proceso de creación de nuevos sentidos en el texto a partir de diversos tópicos abre unas relaciones inéditas con el lector, de modo que el efecto estético se produce en el contexto lingüístico de un poema si logra generar y activar su propia gramática ${ }^{8}$. Rotos los vínculos directos del lenguaje con la realidad, el poema no sólo será capaz de apropiarse de cánones culturales de naturaleza artística, sino también de nutrirse de postulados teóricos procedentes tanto del Estructuralismo, como de aquellas vertientes críticas opuestas al rigor racionalista y científico que éste adquiere durante el siglo XX. En efecto, la vocación metalingüística del poema se sirve de este acervo disciplinar que, como el lenguaje de los mass media lo era en relación con su educación sentimental, participa de la formación académica y artística de los autores del 68. Al mismo tiempo, que el poema incluya elementos teórico-críticos como propios, favorece una expresión que revierte en motivos paródicos que atañen a la reflexión sobre la poesía misma. Esta amalgama de registros contribuye a reforzar el valor irónico y la capacidad indagatoria del poema que, en oposición a la inconsistencia de su representación, se nutre ahora de sus propias reflexiones.

La poética posmoderna asume una prospección epistemológica tendente a expresar críticamente la relación de congruencia entre la palabra y el mundo, pues le interesa, más que comunicar unos contenidos, mostrar qué ocurre en la escritura, al señalar el proceso mismo de su ficcionalidad; con ello, la escritura del poema promueve una lúcida reflexión en torno a su naturaleza ficcional e imaginaria, y su desarrollo textual deriva a un escepticismo ontológico ante la imposibilidad de entender y dar cuenta efectiva de la realidad. El poema manifiesta así su incapacidad para aprehender y comunicar significados absolutos, de modo que la premeditada mezcla del tema con la digresión metapoética termina borrando los límites entre el asunto y el proceso de su reconstrucción literaria. Resulta paradójico, pero significativo, que, en estos poetas, la impronta formal de su escritura acabe por reflejar las limitaciones del lenguaje. Esta atención a los conflictivos límites entre la realidad y su representación verbal tiende a presentar a la escritura como un evento de sí misma incapaz de incorporar algo distinto a esa experiencia negativa del lenguaje. Del mismo modo, por cuanto el proceso verbal es la única realidad posible que el poema puede mostrar, el sujeto poético ha de reconocerse como una instancia lingüística más del evento de la poetización. Para los poetas del 68 , la inutilidad de la poesía implica su incapacidad para acceder a una

\footnotetext{
${ }^{8}$ Cfr. Trabado Cabado (2002: 15-16).
} 
auténtica experiencia vital comprensible fuera del lenguaje: la escritura refleja particularmente este conflicto, y el texto que resulta de ella sería el producto de la colisión entre ambos. Por esta razón, la experiencia poética concita una retórica en negativo, aunque alejada de aquel pesimismo existencial que caracterizó a buena parte de la poesía española de posguerra ${ }^{9}$. Concebida como fracaso y cuestionadas las transferencias directas de la representación simbólica, la poesía posmoderna se expresa como variaciones culturales de la tradición, único modo de expresar los sentimientos y la angustia vital del hombre de nuestro tiempo ${ }^{10}$.

Si la comprensión de una poesía como conocimiento, debatida y considerada por los autores de los 50, es punto de partida fundamental en el desarrollo de la poética posmoderna española, la lírica del 68 abrazará tal componente cognoscitivo para la creación poética mediante una mayor indagación entre lenguaje y realidad ${ }^{11}$. Y, no obstante, la experiencia de conocimiento que resulta de la escritura del poema en éstos últimos resulta distinta, ya que su focalización no se aplica tanto a una expresión personal como al ámbito de las propias representaciones culturales. Por ello, la poesía posmoderna atiende a una intertextualidad inspirada en el arte, y su referencia culturalista o metapoética implica un reconocimiento implícito de los obstáculos verbales del poema para penetrar en la realidad. Se trata, en definitiva, de mecanismos que exponen la fractura entre arte y vida, entre realidad y creación, entre ser y escritura, órdenes irreconciliables entre los que no puede haber intersecciones. Esta separación se lleva a cabo mediante una actualización estilística de corrientes estéticas que proponían una clara noción de autonomía artística (Simbolismo, Purismo, Vanguardias), de forma que en el poema se insertan emblemas discursivos y textuales, ya existentes como realidades culturales, que sirven al poeta de correlato para expresar sus sentimientos de modo indirecto. Bajo este signo culturalista el poeta aparece como glosador de un material artístico preexistente, esto es, de una realidad creada anteriormente a su obra y cuyo acto de escritura lo es de reescritura, simulacro de una realidad a la que se accede por la ficción.

\footnotetext{
${ }^{9}$ Cfr. Prieto de Paula (1996: 118).

${ }^{10}$ Cfr. López, ed. (1998). Según este autor, la poesía vendría a proponerse en la posmodernidad como un juego intertextual, esto es, de variaciones mediante las cuales se expresarían las circunstancias de crisis y de agotamiento cultural en un momento histórico en el que todo ha sido dicho y nada queda por nombrar, como parece expresar el libro Variaciones y figuras sobre un tema de La Bruyère (1974). Si los vanguardistas habían confiado en el amanecer de una nueva cultura que les lleva a romper con el pasado y la tradición de manera violenta, el poeta contemporáneo entiende que el momento presente se corresponde con el cierre de una época cultural en la que resulta imposible introducir novedades. Así, la actividad del escritor tiene como límites el diálogo constructivo, pero también crítico, con la tradición. Este diálogo adquiere frecuentemente la forma de alusiones, comentarios críticos, citas, referencias inventadas o lúdicamente distorsionadas, recolecciones, transposiciones, anacronismos deliberados, mezcla de dos o más modos históricos y, en suma, todo aquello que convierte la literatura del presente en una especie de arqueología cultural (López, ed., 1998: 49).

${ }^{11}$ Cfr. Debicki (1987).
} 
El énfasis del lenguaje para construir dicho simulacro de realidad es aplicado, más que a la comunicación de mensajes unívocos, a la ruptura de la noción moderna de la obra como una instancia autónoma, cuyos significados inmutables eran discernibles para cualquier época ${ }^{12}$. La desconfianza de la poética posmoderna en los significados estables genera un tipo de discurso lírico que descubre en la representación deliberadamente estereotipada del imaginario cultural y en el manierismo retórico una posibilidad de creación original que remite al lenguaje mismo. $\mathrm{Y}$ es que el cambio notable en el registro expresivo de una poesía social, encargada de representar y comunicar vivencias históricas o personales, a otra que indaga en su misma condición ficcional, implica una transformación estética profunda que confirma el giro epistemológico posmoderno, porque «el lugar donde las experiencias (vividas o leídas) se realizan y existen en tanto experiencias transmisibles o abordables por el poema, es uno y el mismo, el lenguaje» (Talens, 1981: 19). Por todo ello, los poetas del 68 recrean en sus primeros textos una tópica culturalista que, en última instancia, es también una experiencia personal de la vida y del arte, si bien ésta renuncia a mostrar una originalidad que no provenga de una particular torsión retórica del tópico elegido ${ }^{13}$. Las imágenes culturales interpuestas en el poema potencian un distanciamiento en el que se renueva la idea barroca de arte como fingimiento: el uso de los correlatos artísticos evita la caída en una expresión sentimental directa no deseada, y permite la creación de experiencias independientes de lo estrictamente personal. Si la función estética reside en el uso formal del lenguaje, entonces deja de ser decisiva la vivencia directa, real, existencial o intelectual que pudiera llevar a la escritura del poema.

La evolución temática del culturalismo a una reflexión metapoética posterior continúa manteniendo este predominio formal del lenguaje, pero éste se dirige entonces a explorar la materialidad verbal del poema de un modo especulativo. El culturalismo inicial de esta generación se repliega a una poética concentrada en sí misma, que orienta la consciencia de su naturaleza artificial al desenmascaramiento de la ilusión representativa $^{14}$. Sin embargo, tanto el emblema culturalista como la metapoesía suponen una misma crítica del lenguaje convencional y de aquellos elementos poéticos mitificados desde el Romanticismo. Si el arrebato había sido una figuración asociada tradicionalmente al poeta, cuyo furor sentimental es activado en la poesía social, en estos autores la imagen del poeta aparece ridiculizada y denostada irónicamente, debido a que la actividad poética es vista como una tarea que no se ajusta a ninguna finalidad teleológica. Frente al fervor de una literatura como justificación, y aun salvación de la existencia, la poesía se considera en la posmodernidad un oficio identificado con el

\footnotetext{
${ }^{12}$ Cfr. Debicki (1989b: 15).

${ }^{13}$ Cfr. Prieto de Paula (1996: 110).

${ }^{14}$ Cfr. Lanz Rivera (2000: 430-434).
} 
artificio verbal, que deslegitima la trascendencia y el sentido metafísico que había fundamentado su carácter utópico y su desvelamiento mediúmnico ${ }^{15}$. Por tanto, el sujeto poético asume su naturaleza estrictamente textual y renuncia al didactismo que había presidido la poesía española durante la posguerra: el poeta ya no escribe para enseñar, porque, éste, lejos de aparecer constituido fuera del lenguaje, sólo puede construirse a sí mismo en el proceso de escritura ${ }^{16}$. Por su parte, el poema certifica que su sentido de realidad y el individualismo del poeta no son más que signos construidos culturalmente, puesto que ambos pertenecen al territorio verbal ${ }^{17}$. En consecuencia, la orientación cognoscitiva de la poética posmoderna habrá de postularse como una actividad tautológica y redundante, porque toda experiencia de realidad se circunscribe a sus límites lingüísticos.

El descubrimiento de las implicaciones ideológicas del lenguaje por la episteme posmoderna permite a estos autores elaborar estrategias que transgreden la centralidad y el logocentrismo del lenguaje, y ofrecer una resistencia a las convenciones artísticas. La poesía se compromete con los valores estéticos mediante unos mecanismos retóricos que tienden a complicar su sometimiento contraviniendo el proceso de su reproducción ideológica por el poder. Tras la integración de las experiencias artísticas modernas en la industria cultural, la poesía posmoderna necesita acometer una crítica radical del lenguaje, donde habitan todas las posibilidades de explicación y representación del mundo como reflejo de una realidad reconocible, o como representación de la realidad oculta de los deseos y percepciones del ser humano: si el poder es inmune al arte, éste también aspirará a metabolizarlo, a hacerlo suyo, a desactivar sus capacidades de subversión para hacer del artista un leal servidor ${ }^{18}$. Así, el poeta posmoderno descubre la paradoja constitutiva de la poesía, ya que, si a ella corresponde una vivencia distinta de la realidad, tal percepción distintiva acaba domesticada en el interior del código; de ahí que, consciente de ello, esta poética se aplique a desintrumentalizar previamente la palabra, y desacredite el efecto de realidad totalizadora que el lenguaje común propone. La voluntad de romper este logicismo, mediante las técnicas del azar o del sinsentido surrealista, propende a desestabilizar la linealidad de la escritura, cuyo carácter secuencial asegura el esquema racionalista del pensamiento jerárquico, y manifiesta una rebeldía contra el sistema que se afirma a través del carácter lógico del lenguaje. Por este motivo, la ilógica razonada del lenguaje en un notable conjunto de textos líricos

\footnotetext{
${ }^{15}$ Cfr. Prieto de Paula (1991: 248).

${ }^{16}$ Para Ángel L. Prieto de Paula (1996: 119), «el poema es el muro contra el que el hombre choca, pues el fracaso de aquél en su tarea de entender el mundo centralmente ocupado por el yo existencial, es el fracaso de ese hombre que lo escribe».

${ }^{17}$ Según Guillermo Carnero, «el lenguaje [...] ha de merecer una atención preferente para el escritor, puesto que su vocación y su castigo consisten en usar precisamente un lenguaje que le entrega y desde el que le condiciona la cultura en que se encuentra situado» (apud Provencio, ed., 1988: II, 42).

${ }^{18}$ Cfr. Rico, ed. (2001: 61-65).
} 
advierte que la creación posmoderna «se convierte en una reflexión sobre el vacío que engendra y sobre el vacío que trata de ocultar, una reflexión sobre el lenguaje como constructor de realidades autónomas, que conlleva el germen de la propia destrucción creativa» ${ }^{19}$. Tras la crisis del realismo en torno a 1963, estos mecanismos vanguardistas de ruptura discursiva -simultaneísmo, acumulación imaginística, enumeración caótica, letrismo, etc.- se encargarán de expresar el fracaso de la razón y su escepticismo ante la idealización de la realidad. Mediante esta fragmentación verbal que tiene en cuenta las fisuras y los vacíos del lenguaje, la escritura poética puede reflejar con mayor fidelidad lo real. El poema, liberado del lastre de su sentido racional, se establece como un escenario verbal en el que el lenguaje reencuentra su primigenia capacidad fundacional.

La poética posmoderna española propicia así una indefinición semántica del signo orientada a desestructurar la centralidad del significado, por cuanto éste es un rasgo fundamental de los textos que no depende de motivos deducibles de él, sino de un acto de voluntad que acaba por privilegiarlo: el cuestionamiento de la convención del significado genera otro proceso mediante el cual los márgenes del enunciado irrumpen en esa centralidad, transgrediéndola ${ }^{20}$. Consciente de que su crítica no puede darse fuera del sistema, esta poética procura desenmascarar sus fundamentos desde dentro, con el fin de no someterse a ellos. Asumida en la lírica la precariedad del lenguaje, los poetas del 68 elaboran una escritura dirigida contra la representación, ya que es éste el espacio que asegura la función simbólica entre lenguaje y mundo, y donde aparece topificado su significado. Se trata de una poesía que intenta contravenir las prácticas de la tradición cultural cuya experiencia estética aparece como un producto de la convención. Desde esta perspectiva, la poesía del 68 asume una estética negativa, apoyada en refutaciones desmitificadoras de la concepción dominante y trascendente del $\operatorname{arte}^{21}$. Y su cuestionamiento del lenguaje lo es asimismo del modelo cultural de la época, lo que implica una irónica denuncia de las falacias que la sociedad ha erigido como absolutos. Tal negatividad aplicada a la creación poética supone para esta generación una manera de reinterpretar y actualizar, desde la desesperanza y la descreencia, la intuición originaria de una experiencia estética sobre la naturaleza y la verdad artística ${ }^{22}$.

Pero veamos más detenidamente los procedimientos retóricos que componen la poética posmoderna española.

\footnotetext{
${ }^{19}$ Cfr. Lanz Rivera (2000: 447).

${ }^{20}$ Cfr. Derrida (1971: 140).

${ }^{21}$ Cfr. Scarano (1991: 321).

${ }^{22}$ Cfr. García Berrio (1994: 262-263).
} 


\section{La metapoesía (o la función crítica del lenguaje poético)}

La metapoesía constituye un procedimiento formal y temático recurrente en la mayoría de los autores del 68, que llega, incluso, a representar una vertiente lírica claramente definida en la poesía española desde los años setenta. La metapoesía es un mecanismo expresivo que propicia un distanciamiento crítico del lenguaje, a partir de la reflexión que acontece en el discurso del poema, y cuyo tema es señalar el funcionamiento de la poesía misma. Desde una perspectiva histórica, la metapoesía tiene su origen en la modernidad y su cultivo acaba por afectar a otros géneros. En el sesentayochismo, lo metaliterario refleja un repliegue estético semejante al realizado por el formalismo de las Vanguardias, sin embargo «mientras los vanguardistas entendieron que la forma era convencional, y exhibieron dicha forma para dar cuenta de su inherente convencionalismo, los autores postmodernos son igualmente conscientes de que el tema es tan convencional como la forma. El discurso se centra así en el discurso mismo, destacando su valor convencional y al mismo tiempo su incapacidad para acceder a la realidad» (López, 1988: 42).

Al convertir la escritura del poema en un escenario verbal que indaga en su propia sustancia, la metapoesía logra dinamizar la función estética del poema. No en vano, ha sido estudiada en la lírica española contemporánea como una expresión sobre lo poético que es asimismo motivo de su propia enunciación ${ }^{23}$. Conviene subrayar esta premisa, porque la especificidad lírica de estos textos la hace particularmente distinta de cualquier otra clase de reflexión teórica: la característica de este sistema es su capacidad de indicar al interior del lenguaje para reflexionar sobre lo poético, su naturaleza estética y su escritura. En consecuencia, la referencia de la poesía sobre sí misma es el principio estructurador en estos textos líricos, por cuanto tematiza tal reflexión bien como proceso bien como resultado ${ }^{24}$. Este valor autorreferencial coincide, además, con una de las convenciones pragmáticas del género en tanto parece querer anular en él su dependencia en relación con el ámbito referencial de los estados de hecho, y proponerse como autorrevelación, esto es, como un lenguaje emergente separado de las construcciones referenciales que la mimetización de acciones históricas imponen a los sistemas narrativos. A este propósito, José María Pozuelo señala la total coincidencia de los teóricos al afirmar, incluso desde postulados distintos, que la función reflexiva es un rasgo específico de la lírica: todo poema tiende, pues, a lo metapoético ${ }^{25}$. Lo metaliterario se correspondería así con el conjunto de los enunciados que el texto literario despliega para la tematización reflexiva acerca de la literatura, de modo que la

\footnotetext{
${ }^{23}$ Véase Sánchez Torre (1991).

${ }^{24}$ Según Guillermo Carnero (1983: 57), la metapoesía es un «discurso poético cuyo asunto, o uno de cuyos asuntos, es el hecho mismo de escribir poesía y la relación entre autor, texto y público».

${ }^{25}$ Cfr. Pozuelo Yvancos (1994: 181).
} 
metaliteratura implicaría afirmar que todo texto metaliterario es, a su vez, literario. Únicamente en este nivel podría hablarse de ella, porque es aquí donde la reflexión acerca de lo literario aparece como un principio estructurador del sentido del texto. Esta focalización no repercute exclusivamente en el discurso, pues afecta también al modo de aprehender la realidad, es decir, a los mecanismos de comprensión del mundo, si se tiene en cuenta que la metaliteratura se encarga de mostrar la ficción del texto literario que los contiene. Esta insistencia en lo ficcional contribuye a establecer una delimitación crítica entre ficción y realidad, de modo que este procedimiento metaliterario renueva la dinámica tensión que, desde el Romanticismo, se da entre literatura y vida.

En este sentido, la metapoesía contribuye especialmente a superar la visión tradicional del código poético, ya que, desde la modernidad, la tematización de la crisis del lenguaje hace de ella una especie de teoría implícita de lo poético ${ }^{26}$; la lírica moderna se desdoblará en crítica porque necesitaba fundar su actividad de manera autónoma. Con esta vuelta sobre sí misma, la poesía moderna alcanzó un tipo de reflexión relevante que fundaba los planteamientos de la metapoesía contemporánea, que se abastece incluso del reducto teórico. Así, la Semiótica o la Estética de la Recepción aportan premisas que afectan a la consideración de lo literario y poético, pues su ámbito sobrepasa propiedades lingüísticas tradicionales para relacionar conjuntamente las instancias de texto, lector e intertexto. La metapoesía en los autores del 68 no pasa por alto que estas nuevas relaciones afectan a todo un conjunto de convenciones y expectativas que garantizan que un texto pueda ser entendido como poético; es decir, las propiedades de un texto literario no se circunscriben a las características del mismo, sino que incorporan determinadas expectativas reconocibles en su recepción ${ }^{27}$. Y, en tanto que la metapoesía es poesía, el metapoema, como producto que habla de ella, dinamiza y moviliza las expectativas de recepción del poema mismo. En tal caso, la competencia del lector habrá de contener cierto grado de especialización para que la creación de sentido alcance una significación satisfactoria en estos textos. Si corresponde establecer a cada lector concreto la relación entre texto y realidad, esta tarea se complica cuando dicha relación se traslada al texto y a su enunciación: son los límites formales del texto y la competencia del receptor los que determinan el ejercicio de restricciones a que es sometida la plurisignificación semántica del metapoema. Desde su perspectiva de recepción, los estímulos verbales del metapoema serán activados por cada lector sólo en una porción de sentido posible. Este hecho dispensa a la metapoesía de un grado superior de revelación: su misma naturaleza poética permite al receptor una implicación estética en el texto cuyas consecuencias son

\footnotetext{
${ }^{26}$ Cfr. Cabo, ed. (1999: 13-14).

${ }^{27}$ Cfr. Sánchez Torre (1991: 136).
} 
desconocidas para esa otra reflexión teórica. Sin duda, esta tensión entre lenguajes aumenta la complejidad de su recepción, pero con ella, aparece además una nueva expectativa: la de «lectura» del poema, que establece su consideración «meta», lo que identifica al metapoema como $\mathrm{tal}^{28}$. El metapoema presenta como referente su acontecer textual mismo, que, mostrándose en su decir, no desea comunicar o intervenir en el mundo, sino verbalizar esa experiencia intrínseca a su propia enunciación lírica; de ahí que la escritura metapoética suponga, más que un mero valor compositivo en sí mismo, la asunción implícita de una crítica al lenguaje.

El cultivo de una poesía de temática autorreferencial se ligó en la Modernidad a la crisis general del pensamiento occidental y pasó a ser una modalidad idónea para expresar el nuevo espíritu autocrítico de la misma ${ }^{29}$. Esta dimensión autocrítica de la poesía origina un tipo de metadiscurso que permite dar una salida a la crisis de la poética romántica, y posibilita el ingreso de la lírica en la modernité $e^{30}$. La crisis del lenguaje propició una vuelta de la lírica moderna hacia sí, de modo que la reflexión acerca de lo poético se convirtió en objeto de su propia enunciación ${ }^{31}$. Con este giro metapoético, la poesía parece obedecer al anuncio hegeliano de la «muerte del arte», pero, contrariamente a su previsible final, funcionaría como renovadora solución a los clichés de la retórica romántica. Este repliegue del lenguaje del poema favorece su opacidad, ya que, al remitir sólo a su naturaleza formal, el signo debilita su proyección extraverbal en beneficio de una autorreferencialidad. En la medida en que es representación de sí mismo, el lenguaje poético sufre un fuerte proceso de ensimismamiento que promueve una emancipación de la realidad empírica. Como se sabe, la poesía de Mallarmé y de Valéry atiende a este nuevo hito estético en el proceso simbolizador de la lírica occidental: su formulación trata de evitar la mención del término real para aludir a él mediante una evocación simbólica ${ }^{32}$. Tras experimentar el vértigo de la página en blanco, la lírica redescubre y recobra su vigor con el desplazamiento de la reflexión poética al poema mismo. A partir de Mallarmé y de Rimbaud, la poesía moderna será expresión de la brecha insalvable entre el sujeto y el mundo.

\footnotetext{
${ }^{28}$ Cfr. Sánchez Torre (1991: 150).

${ }^{29}$ Octavio Paz y Roland Barthes observan que este tipo de textos de temática autorreferencial se inicia en la Modernidad. Para Paz, la poética moderna se corresponde con este carácter autorreflexivo: «la escritura poética es la revelación de sí mismo que el hombre se hace a sí mismo» (Paz, 1952: 233-234). El crítico francés vincula este desdoblamiento de la literatura con la crisis que la conciencia burguesa muestra en el siglo XIX (cfr. Barthes, 1973: 89).

${ }_{30}^{30}$ Sobre este proceso, véanse Friedrich (195) y Marcel (1983).

${ }^{31}$ Cfr. Hamburger (1992).

${ }^{32}$ Así lo hallamos formulado: «Nommer un objet, c'est supprimer les trois-quarts de la jouissance du poème...; le suggérer, voilà le rêve. $C^{\prime}$ est le parfait usage de ce mystère qui constitue le symbole: évoquer petit à petit un objet pour montrer un état d’âme» (Mallarmé, 1891: 869).
} 
Durante la primera mitad del siglo XX, la expresión metapoética de la lírica española se bifurca en dos líneas estéticas contrapuestas, aunque formalmente parecidas: la denominada poesía pura de un lado, y, de otro, la poesía intranscendente, que resulta del juego verbal vanguardista. A éstas, se opondrá, luego, el modelo lírico comprometido, fruto del proceso literario rehumanizador acorde con la circunstancia sociopolítica $^{33}$. Como se sabe, la poesía pura asume el sentido inmutable de lo bello y sigue la ideología de una «deshumanización» aupada en la noción kantiana moderna de la autonomía estética: aludir sin nombrar lo real para construir el espacio de una realidad artística no contaminada por esa otra empírica, haciendo bueno el conocido comentario de Ortega de que el objeto artístico sólo es artístico en la medida en que no este es real. Frente a ésta, el valor lúdico del vanguardismo español tiende a disgregar todo signo de trascendencia. Y, no obstante, ambas tendencias responden al mismo componente ideológico pequeño-burgués que las alumbra: tanto la forma exenta como la lúdica se corresponden con las dos caras de una antinomia que incita a una autonomía de lo estético como emancipación idealista de lo empírico ${ }^{34}$. Si el poeta acomete en la modernidad la ardua tarea de preservar esa unidad ideal vislumbrando las correspondencias que le brinda la naturaleza, éste tenderá en la posmodernidad a marcar explícitamente la naturaleza textual de la realidad, cuya representación y sentido resulta de construcciones ideológicas y culturales particulares ${ }^{35}$. Así, la metapoesía contemporánea deja de discriminar entre contenido y forma, porque su indagación acerca del lenguaje concluye que ambas entidades son convencionales. Pero esta circunstancia, lejos de marcar una crisis de la escritura, ofrecerá a los poetas españoles del 68 unas «posibilidades ilimitadas» (Carnero, 1983: 57) para la creación. A partir de aquí, el conocimiento crítico de la realidad mediante el leguaje, que establece la episteme posmoderna, legitima al metapoema como recurso idóneo para la reflexión sobre el poema y su relación con el mundo, expansión gnoseológica en el texto que conlleva una revisión crítica de sus representaciones culturales.

A pesar de las opiniones encontradas acerca de la función desenmascaradora de los mecanismos represores del lenguaje atribuidos a la metapoesía, ésta constituye en la lírica española de los años setenta una tendencia reconocible que, dada su especificidad reflexiva, posibilita un asedio crítico a las convenciones retóricas y a la norma poética. Desestimados en la posmodernidad los principios estéticos rectores de autonomía y emancipación, la creación poética posmoderna se muestra especialmente consciente de su inclusión simbólica en la esfera ideológica que afecta a la producción global. Si toda actividad artística expresa una ideología, que es remedo de su propio modelo de

\footnotetext{
${ }^{33}$ Cfr. Geist (1980).

${ }^{34}$ Cfr. García (2001: 38-42).

${ }^{35}$ Cfr. Navajas (1987: 15).
} 
producción, la metapoesía posibilita una orientación crítica en su misma expresión, pues su escritura refleja la lucha del lenguaje por mostrarse fuera de normas y códigos ${ }^{36}$. En su caso, la metapoesía incide reflexivamente no sólo en la naturaleza discursiva de la propia poesía, sino también en el modelo ideológico de realidad a la que ésta remite, ya que, en sus propuestas textuales más radicales, el carácter gnoseológico de lo metapoético intenta transgredir la codificación normativa del lenguaje que rige en las relaciones de la palabra con una exterioridad, e insiste en el hiato existente entre el mundo y el signo poético.

Frente a su moderna reivindicación de autonomía, lo metapoético supone en los autores del 68 reconocer que la mención o referencia de toda realidad limita con su estricta naturaleza verbal: de tal noción se desprende la incapacidad de la poesía para trascender los límites del lenguaje y representar fielmente lo que se halla fuera de él ${ }^{37}$. Por tanto, la metapoesía no es sólo un discurso cuyo referente se centra en la propia sustancia de lo poético como realidad última, sino que su discurso también activa una crítica sobre el lenguaje, al intentar descubrir y cuestionar las estrategias sistematizadoras del mismo. En opinión de Juan José Lanz, «el lenguaje de la metapoesía expresa su rebeldía contra el lenguaje instaurado por el poder, en una crítica de éste semejante a la que lleva a cabo el culturalismo, pero esta crítica se realiza precisamente desde la misma experimentación del lenguaje, es decir, el metapoema cae en la paradoja de negar la capacidad expresiva del lenguaje desde el mismo lenguaje y, por lo tanto, negando el sistema que lo sustenta y afirma» (Lanz Rivera, 2000: 434). En definitiva, el planteamiento crítico de la relación entre lenguaje y realidad conlleva en el metapoema una negación del sistema en que todo lenguaje de poder se sustenta.

Precisamente aquí radica la polémica acerca de la práctica metapoética en los poetas del 68. Por un lado, en su conocido estudio de la poesía de Carnero, Carlos Bousoño atribuye a la metapoesía de esta generación una función desenmascaradora del carácter represivo, uniformador y deshumanizador del poder ${ }^{38}$. Según sus postulados, corresponde a los poetas del 68 ser eslabón último de una «edad poscontemporánea» definida por un individualismo radical que explicaría la profunda crisis de los valores racionalistas: la «verdadera realidad» que asume la escritura poética de estos autores proviene de su «marginalidad» respecto de una razón racionalista abstracta, centralizadora, desatenta a lo individual y utilitarista. Enfrentados al poder social establecido, estos autores manifiestan una fidelidad al momento histórico de crisis que les toca vivir, al rechazar el utilitarismo de la razón instrumental y de su conocimiento sistemático. Su reflexión crítica en torno al lenguaje contradice el ideal racionalista, de

\footnotetext{
${ }^{36}$ Al respecto, véase Rodríguez (1994).

${ }^{37}$ Cfr. Sánchez Torre (1989: 24-29)

${ }^{38}$ Cfr. Bousoño (1984: 246-250).
} 
modo que el planteamiento de la poesía como metalenguaje comportaría, según éste, una corrección «a la potencia deformadora de la realidad y la experiencia que posee el lenguaje en cuanto código dominado y manipulado» (Bousoño, 1984: 247-248). Desenmascarados los mecanismos represores del lenguaje instrumental y los estereotipos que configuran la realidad, la metapoesía asumiría el carácter imaginario del poema como realidad misma; es decir, el arte no tiene la misión de representar el mundo real, sino la de representarse a sí mismo. En esto consiste, para Bousoño, la particular «marginalidad» de estos poetas respecto de la realidad, ya que, ubicada su escritura en el espacio irreductible del poema, éste crea su propio referente y se muestra como representación de la ficción ${ }^{39}$.

Por otro lado, Jenaro Talens disiente del excurso teórico acerca de lo metapoético que Bousoño proponía para la generación de Carnero, pues tal aplicación resulta equívoca y ambigua cuando éste aborda la función social de estos autores ${ }^{40}$. En su prólogo a la poesía de Martínez Sarrión, Talens contradice uno por uno los argumentos de «marginalidad», «metapoesía» y «culturalismo» que sustentaban el estudio de Bousoño. En relación con lo que aquí nos interesa, Talens destaca el carácter problemático del segundo término, que es planteado por Bousoño como una modalidad crítica de escritura. Para Talens, en cambio, la metapoesía es resultado del uso metafórico de «metalenguaje», teniendo en cuenta que éste es un sistema semiótico cerrado y articulado, cuyos elementos tienen el lenguaje como referencia. Por tanto, la metapoesía es una clase más de poesía, con la especificidad de que se tiene a sí misma como referente. Pero si el valor de esta inmanencia le lleva a ser un lenguaje distinto, debería poseer la característica básica que a todo lenguaje le es propia, esto es, poder articular y estructurar su universo referencial en unidades mínimas, con lo que «o bien es redundante o bien estructura un universo que previamente no lo estaría, lo que de entrada es contradictorio con la definición misma de poesía como lenguaje» (Talens, ed., 1992: 42). El universo referencial de la poesía como lenguaje (o metapoesía) implica la sobresignificación de una realidad conformada históricamente como literatura, de cuyo formalismo idealista no debe colegirse la negación de la relación de un texto con la realidad, como afirma Bousoño. Si todo lenguaje lo es de y del poder, la función metapoética propondría una reflexión sobre éste que no tendría por qué implicar necesariamente un desenmascaramiento de sus mecanismos represivos. Para Talens, lo que sí puede establecer la metapoesía es una distinción gradual en su reflexión, según su práctica asuma un lenguaje «analítico», «reflexivo»o propiamente «crítico». Frente a

\footnotetext{
39 «Si el contenido de la poesía es, para Carnero y la nueva generación, no la realidad y ni siquiera su experiencia, sino la ficción en cuanto ficción (aunque ésta, por supuesto, se relacione con la vida), el interés del poeta no irá ahora hacia las dos primeras cosas, sino hacia la tercera, la ficción, o sea el arte, lo artístico como tales» (Bousoño, 1984: 253).

${ }^{40}$ Cfr. Talens, ed. (1992: 41).
} 
los dos primeros, el último asumiría esta problemática no como medio de análisis lingüístico, sino usándose gratuitamente, destinándose él mismo como un goce estético ajeno a su finalidad útil o a sus implicaciones de saber.

Al margen de esta polémica, otros autores se han tratado otros aspectos interesantes en la consideración de la práctica metapoesía en la generación del 68. En este sentido, Prieto de Paula se pregunta si, vinculado al espíritu rebelde de los años sesenta, aquel carácter presuntamente «desvelador» de los mecanismos represores asignados por Bousoño a la metapoesía, lo era también «debelador», o si, «como parece más probable, se limita a evidenciar que se está al cabo de los mismos con una sabiduría de la realidad pareja al escepticismo sobre la capacidad de modificarla» (Prieto de Paula, 1996: 230). Según este autor, la metapoesía escrita por el grupo de los novísimos propondría un acercamiento intertextual a la «poesía pura», actualizando modos graduales de indagación verbal a partir de su relación con el tipo de reflexión en el texto. En primer lugar, algunos autores escriben un tipo de «poesía reflexiva», primer grado en esa relación del lenguaje del poema consigo mismo; aquí, la reflexión sobre la poesía misma abre una senda de conocimiento que sugiere una caracterización autónoma de lo poético en relación con la realidad empírica, de modo que este carácter metapoético no difiere sustancialmente del modelo moderno de aquella poesía intelectual (o pura). La poesía reflexiva es la base de ese otro segundo modo, superior en grado expresivo, cuyo contenido, al hacer de la propia indagación su tema, propicia «el que ésta se vuelva introspectivamente hacia sí, de manera que la lámpara de que nos servimos para contemplar acaba por ser objeto de su propia luz» (Prieto de Paula, 1996: 225). Esta vuelta hacia sí constituye la expresión de la «poesía refleja», que, identificada con lo puramente metapoético, radicaliza el procedimiento y la dimensión cognoscitiva de una reflexión que muestra el fracaso del poema por obtener el rango ontológico del objeto $^{41}$.

En el camino de su irrupción en la tradición contemporánea española, los poetas del medio siglo formularon ya un tipo de poesía cuyo signo cognoscitivo se ligaba al proceso de la escritura misma. Observada una relación entre la concepción del poema como medio de conocimiento y la proliferación metapoética en su escritura, los autores del medio siglo iniciaron una crítica del lenguaje que resultará esencial para los poetas de la generación siguiente. Muchos textos de Gil de Biedma, Claudio Rodríguez, Francisco Brines, Ángel González o José Ángel Valente manifestaban una introspección verbal a partir de una reflexión formal para referir sus vivencias temporales y existenciales. Para éstos, si la experiencia del conocimiento estético procede de la propia escritura del poema, la reflexión metapoética que deriva de ella nunca puede ser

\footnotetext{
${ }^{41}$ Cfr. Silver (1985: 23-24).
} 
previa o hallarse codificada antes de que aquél exista. Según lo anterior, el texto poético vertebra una percepción de la realidad, material e histórica, cuyo conocimiento se realiza mediante un modo verbal insustituible. Esta orientación reflexiva del lenguaje asegura que el resultado cognoscitivo es inherente al proceso de la creación del poema $^{42}$, de modo que el material verbal de la composición es capaz de mostrar una experiencia excepcional e irrepetible.

Partiendo de esta dimensión cognoscitiva, la práctica de la metapoesía no sólo reclama a los autores del 68 su atención sobre el conflicto permanente que la escritura mantiene con la realidad, sino que establece también una tensión inédita entre poesía y metapoesía, fruto de la mezcla de ambos extremos. Según afirma Prieto de Paula, «lo metalingüístico concierne, pues, al objeto lingüístico en la medida en que éste ha visto alterarse su conexión con el mundo. La crisis de la que es testimonio la metapoesía parte de una relación biunívoca entre poesía y realidad, ahora modificada, y diseña otra relación entre poesía y metapoesía, también biunívoca aunque con tendencia a la fusión de ambos términos en el mismo objeto: el metapoema» (Prieto de Paula, 1996: 227). En la generación del 68, el texto metapoético manifiesta frecuentemente el choque entre un lenguaje poético y otro teórico dentro del proceso mismo de verbalización poética. Se convierte así la reflexión sobre la escritura poética en materia del poema, de modo que la manifestación de la relación entre sujeto y objeto poéticos se establece no ya como una complejidad de la experiencia, sino como una experiencia de la complejidad que emana de lo metapoético ${ }^{43}$. El efecto estético es un ensimismamiento del signo poético, alejado cada vez más de la representación, y convertido en una forma tendente al silencio, como metáfora de la frustración que produce no poder alcanzar la plenitud del estatuto ontológico. Por cuanto la especificidad del metapoema consiste en el desplazamiento del contenido a los aspectos de su enunciación misma, es frecuente que el tema, la técnica y el comentario estén premeditadamente mezclados, de manera que autor implícito y lector real colaboran de diversas maneras en el texto. La construcción verbal de un texto con una significación abierta implica un tipo de recepción activa en la que resultan inválidos los hábitos tradicionales de lectura. En suma, el texto

\footnotetext{
${ }^{42}$ Para Claudio Rodríguez, «la poesía es, sobre todo, participación. Nace de una participación que el poeta establece entre las cosas y su experiencia poética de ellas, a través del lenguaje. Esta participación es un modo peculiar de conocer [...]. Una característica esencial de este último consistiría en que lo que se conoce acontece, está actuando en las tablas del poema. Y sólo ahí. El proceso del conocimiento poético es el proceso mismo del poema que lo integra» (apud Provencio, ed., 1988: I, 168). También, para José Ángel Valente, «el poeta no opera sobre un conocimiento previo del material de la experiencia, sino que ese conocimiento se produce en el mismo proceso creador y es, a mi modo de ver, el elemento en que consiste primariamente lo que llamamos creación poética. El instrumento a través del cual el conocimiento de un determinado material de experiencia se produce en el proceso de la creación es el poema mismo. Quiero decir que el poeta conoce la zona de realidad sobre la que el poema se erige al darle forma poética: el acto de su expresión es el acto de su conocimiento» (Valente, 1971: 9).

${ }^{43}$ Cfr. Sánchez Torre (1991: 130).
} 
metapoético expresa una experiencia del lenguaje procedente de la reflexión formal que el poeta entabla sobre la propia escritura del poema. El resultado de esta escritura precisa de una descodificación que debe afrontarse mediante una recepción que exige una especialización y una mayor implicación del lector: este se verá obligado a integrar esa experiencia de complejidad que confiere al poema nuevos horizontes de significación, enriqueciéndolo estéticamente.

Asimismo, la dominante metapoética del 68 plantea una deconstrucción del lenguaje como una indagación ontológica sobre sus limitaciones simbólicas que frustra, por falaz, cualquier tentativa de reconstrucción vital en el poema. Por ello, la metapoesía señala los extremos de esa distancia existente entre la palabra, la realidad y su representación ${ }^{44}$. La insistencia en la tensión generada por los códigos que integran el sustrato verbal del poema no expresa otra cosa que la fractura entre lenguaje y mundo: el metapoema constata las dudas y la desconfianza en su propia capacidad de representación. De este modo, la única realidad a que éste alude es el poema mismo, puesto que su contenido es una manera oblicua de referencialidad que no conduce a una exterioridad, sino a su simulacro ${ }^{45}$. Ello remite al espacio textual donde el poema acontece para crear él mismo una apariencia de realidad que se sabe diferente de esa otra empírica. En tanto que proyección reflexiva de su propia naturaleza verbal, el metapoema desvela las condiciones de su condición como máscara o ficción ${ }^{46}$. El metapoema se propone en la lírica 68 como una estrategia retórica tendente a resaltar un ideal de poesía que resulta insatisfactorio y frustrado: esta pérdida de fe en la creación artística despierta inversamente un lúcido y crítico entusiasmo sobre la naturaleza poética en la época del desengaño posmoderno ${ }^{47}$.

\section{La indeterminación del significado poético}

Acabamos de ver que la metapoesía comporta una autorreflexión crítica sobre su forma y su contenido. En ella, el resultado estético suele ir ligado a un efecto de vaguedad semántica procedente de privilegiar en su enunciado la plurisignificación del

\footnotetext{
${ }^{44}$ Cfr. Ferrari (1996: 143).

${ }^{45}$ Según afirma Juan Ferrater, «en principio toda poesía es oblicua, toda poesía traspone los términos usados a un plano que podríamos llamar de ficción en contraposición al uso denotativo real del habla normal. Toda realidad representada en el poema ingresa en un orbe de significación donde los caracteres objetivos que la cosa pueda tener no importan como realidades, sino sólo y en la medida en que valen para la unidad del sentido del poema. Esto significa que los términos usados no tienen una función denotativa real (actual o potencial), sino sólo pretendida, fingida, y nunca cumplida en la realidad» (Ferrater, 1968: 160-161).

${ }^{46}$ Cfr. Lanz Rivera (1990: 35).

${ }^{47}$ Según Ángel Luis Prieto de Paula, «la contemporaneidad multiplica los motivos por los que el poema no remite con fidelidad al universo externo. Tales motivos, aunque no exclusivos de este tiempo, encuentran ahora su mejor caldo de cultivo, bien sazonado con el escepticismo, el agotamiento de la ingenuidad creativa, la ultraconsciencia» (Prieto de Paula, 1996: 229).
} 
poema $^{48}$. Se favorece así una indeterminación de los símbolos poéticos que, si configurada desde el nivel textual, se proyecta también a su recepción, según el grado de ambigüedad con que el texto dispone sus significados. A diferencia de la poética moderna tendente a consignar significados estables y perdurables, la indeterminación es un mecanismo retórico posmoderno que proporciona a las estructuras semánticas del poema una imprevisibilidad, zona de incertidumbre interpretativa nunca agotada en las múltiples recepciones de los textos. La imprevisibilidad estructura el texto en diversos niveles de significación, por lo que la visión unitaria del poema se disgrega. El empleo de perspectivas diversas, de diferentes códigos que se mezclan en el cuerpo del poema, o de referencias al proceso mismo de la creación da como resultado unos textos decididamente abiertos. Esta circunstancia incide especialmente en la ambigua significación del poema, despierta la atención en el lector y refuerza una multiplicidad interpretativa que distingue al mensaje poético de otros. Para Umberto Eco, «el mensaje ambiguo predispone para un número elevado de selecciones interpretativas. Cada significante se carga de nuevos significados, más o menos precisos, no a la vista del código, sino a la luz del idiolecto que organiza el contexto, y a la luz de otros significantes que reaccionan uno con otro, como para buscar el apoyo que el código violado ya no ofrece. De esta forma, la obra transforma continuamente sus propias denotaciones en connotaciones, y sus propios significados en significantes de otros significados» (Eco: 1978: 167). El dinamismo del código poético tiene en la indeterminación del significado un elemento imprescindible, puesto que la riqueza semántica de los textos posmodernos procede precisamente de la ambivalencia de sus significados, rompiendo así el carácter cerrado de los textos líricos modernos.

Es durante la segunda mitad del siglo XX cuando, en la poesía española, se produce un paulatino cambio en la concepción simbólica del poema: su noción como emblema estable de la realidad y de la experiencia humana entra en declive. Según Andrew P. Debicki, «al romper las convenciones y las líneas de demarcación tradicionales, según las cuales la ficción del arte yace separada de la realidad de la vida (y del lector), esta poesía nos invita a cuestionar los estilos y enfoques expresivos anteriores, y también las ideas previas acerca de la integridad del texto. De esta manera nos lleva a un mundo en el que los significados del poema tienden a perder su determinación, y en el que la lectura y la escritura comienzan a confundirse. Un mundo que muchos críticos teóricos, bajo perspectivas diferentes, han llamado postmoderno» (Debicki, 1997: 231). Esta poética basada en el principio de indeterminación moviliza una serie de recursos expresivos orientados no sólo a caracterizar el texto por su grado de incertidumbre semántica, sino también a socavar la naturaleza referencial del signo.

\footnotetext{
${ }^{48}$ Cfr. Sánchez Torre (1991: 180).
} 
Esta facultad retórica conduce a un extrañamiento del lenguaje que posibilita nuevas significaciones en el interior del texto, si bien éstas proceden de espacios no fijados e invisibles del idioma.

El concepto teórico de la indeterminación procede del ámbito de la fenomenología, si bien se aplicó posteriormente en la Poética de la Recepción, disciplina que, como se sabe, aborda la capacidad hermenéutica del receptor para interpretar los textos literarios. Durante los años treinta, Roman Ingarden, precursor de los postulados de la Escuela de Constanza, consideró que la obra literaria es un objeto puramente intencional y heterónomo cuyo resultado depende de un acto de conciencia que lo diferencia tanto de las objetividades reales como de las ideales ${ }^{49}$. En contraste con los objetos reales $-\mathrm{u}$ objetivos, en cuanto son universales, inequívocos $\mathrm{y}$ determinados-, los representados en la obra literaria se exhiben como lugares o puntos de indeterminación. Según esto, la obra dejaría muchos elementos de su propia constitución ontológica en un estado potencial, debido a que es la suya una entidad funcional de esquemas cuyas zonas de indeterminación (o elementos latentes) resuelve el lector en su tarea de recepción. Si ésta se realiza con una actitud positiva, el objeto artístico que la obra es se convierte en un objeto estético pleno. A partir de aquí, la lectura se concibe como una actividad cognitiva que lleva al lector a rellenar el hueco de las indeterminaciones con que tales objetos aparecen en el texto. La labor cognitiva de la lectura resulta así fundamental, pues concreta el significado de las unidades de sus diferentes estratos; ella es el modo de objetivación sintetizante por la que cada receptor incorpora, en el rellenado de tales esquemas, sus valores subjetivos.

Partiendo de tal propuesta, este modelo de concreción hermenéutica desarrollaría una aplicación histórica en otros autores, de modo que la subjetividad del lector dejaba de ser el ámbito donde se resolvía el problema de la interpretación, para adquirir ésta, a partir de entonces, naturaleza histórico-cultural. El concepto fue retomado por W. Iser, cuyas aportaciones lo sitúan en el proceso de lectura como elemento central en la creación de significado de la obra y, también, de su interpretación: en el acto de lectura se genera una significación textual, resultado de la interacción entre las señales textuales y la competencia del lector ${ }^{50}$. Tras analizar el proceso de la lectura, Iser estudia la estructura comunicativa de la ficción y de sus asimetrías en relación con la comunicación ordinaria, y concluye que sólo existe el camino del texto para el lector, ya que sus preguntas sólo pueden ser respondidas por las señales extraídas de él. Su concepto de vacío (o hueco), aunque impreciso para algunos críticos, se vincularía al término de indeterminación de Ingarden, y vendría a ser una especie de trazado textual

\footnotetext{
${ }^{49}$ Cfr. Pozuelo Yvancos (1988: 110-113).

${ }^{50}$ Cfr. Iser (1976: 9-10).
} 
que necesita completarse con las presuposiciones del lector y con las discontinuidades del discurso ${ }^{51}$.

Por lo que respecta a su consideración pragmática, la indeterminación es un fenómeno de plurisignificación inherente a los mensajes literarios, que activa la convención de «mayor significación» por la que se invita al lector, en virtud de una actitud de recepción motivadora, a llevar su interpretación al lugar de las potencialidades significativas ${ }^{52}$. En este sentido, la poética posmoderna española asume que la significación del poema forma parte de un circuito que excede su creación textual y se resuelve en el ámbito pragmático, donde queda estipulado el carácter comunicativo excepcional de lo lírico. La configuración abierta del significado responde al uso de recursos que potencian una intervención interpretativa más libre, aunque la estructura compositiva del texto continúe regulando el orden de unos sentidos dispuestos a la cooperación del receptor ${ }^{53}$. Si el poema establece en todos sus niveles una interpretación prevista en el proyecto compositivo, éste activa a su vez la corriente alternativa de significados que compone su estructura plurisignificativa. Esta apertura en el significado desborda el ámbito tradicional de la sugerencia y de las connotaciones, y favorece el carácter relacional e imprevisible de unas significaciones abiertas, características de la epistemología posmoderna. Mediante esta apertura, el signo poético hace problemática la forma convencional que rige toda percepción de la realidad, e incide en la condición provisional (o relativa) de los significados. La indeterminación emana, pues, de la convergencia en el poema de diversos mecanismos retóricos inmanentistas estudiados por la Retórica General Textual (tropología, topoi clásicos y modernos, ideologemas, etc.), pero también del conjunto de reglas y expectativas pragmáticas que confieren al género lírico y a su recepción un carácter dinámico, muy distinto del de otros modos de enunciación discursiva ${ }^{54}$.

Otra función específica de la lírica, añadida a su reflexión sobre el lenguaje como medio de representación, es la naturaleza controvertida del sujeto y de los deícticos (shifters), cuya pluralidad e imprecisión semántica caracterizan la situación comunicativa instaurada en la enunciación poética ${ }^{55}$. Tales elementos inciden en configurar una experiencia del lenguaje en ausencia de mundo, de modo que la ficcionalidad inherente a la enunciación lírica se sustenta en unos índices subjetivos verbales conducentes a la indefinición de los significados del poema ${ }^{56}$. En poesía, la palabra no tiende a crear sólo su propio espacio de libertad, sino que su propensión al

\footnotetext{
${ }^{51}$ Cfr. Pozuelo Yvancos (1988: 118-120).

${ }^{52}$ Cfr. Schmidt (1978: 194-212).

${ }^{53}$ Cfr. Eco (1963).

${ }^{54}$ Cfr. Riffaterre (1978).

${ }^{55}$ Cfr. Paz Gago (1999: 99).

${ }^{56}$ Cfr. Cuesta Abad (1997: 126-127).
} 
aislamiento formal conlleva también anular toda situación contextual que pueda determinarla: tal circunstancia afecta ineludiblemente al estatuto ontológico de la referencia poética, cuyo carácter inespecífico aparecería situado en un lugar intermedio entre la realidad y la ficción ${ }^{57}$. La poética posmoderna propicia así una diseminación de los sentidos del texto, al ser la indeterminación un fenómeno de plurivalencia que afecta en distinto grado al conjunto de los recursos expresivos en la producción del texto y al dinamismo de los elementos que intervienen en su descodificación. Esta radicalización del fenómeno polisémico actualiza la idea mallarmeana de que lo poético sólo se determina en su abolición, hecho que conduce a la autonomía de su sentido. En cambio, la poética posmoderna plantea el espacio de indeterminación textual no sólo como ambigüedad, sino también como una posibilidad ilimitada de proyectar sobre la forma poética un conjunto indefinido de procesos hermenéuticos ${ }^{58}$. La indeterminación propiciaría así una especie de discontinuidad juguetona que cuestiona el principio de unidad orgánica propio de la obra moderna ${ }^{59}$. Aunque la desestabilización del significado no es exclusiva de la poética posmoderna, la indeterminación cobra en ella una función distintiva, lo que repercute en la negación de la obra literaria como absoluto ontológico portador por sí mismo de un significado perdurable.

La propiedad indeterminada de algunos textos líricos modernos ya sirvió para confrontar las poéticas simbolista y vanguardista: frente al valor inmutable de los símbolos, su fragmentación vanguardista presentaba esta trascendencia como juegos de sentido $^{60}$. El fenómeno de la plurisignificación adquiere en las Vanguardias una importancia que se acrecentará por las reflexiones conflictivas que instaura el arte en relación con la realidad y sus modos de representación simbólica. No extraña que la lírica vanguardista española presente, junto al cultivo de la poesía pura, una poética irreverente con la trascendencia simbolista, ya que se trata de una modalidad lírica no sometida a fines teleológicos. A esta vertiente pertenece la poesía de algunos autores del 27 (Pedro Salinas y, sobre todo, Juan Larrea), pues la creación de sus textos responde a este fenómeno de semántica abierta y plurisignificativa. Tras la leve incidencia vanguardista, la continuidad de una poética lúdica e indeterminada, soterrada en ciertos movimientos y autores marginales, configuró una alternativa estético-moral a las

\footnotetext{
${ }^{57}$ Según José María Paz Gago, el discurso lírico admite una gradación que le permite aproximarse o alejarse de cada uno de los dos extremos, real o ficcional, según el mecanismo concreto explotado por cada poema y por cada movimiento poético. Así, «[e]n unos casos el yo lírico expresará emociones realmente sentidas, identificándose en mayor o menor medida con el poeta, y en otros ficcionalizará al máximo el discurso, expresando sentimientos o fenómenos puramente imaginarios, artificialmente revividos o simplemente simulados, demostrando su innegable condición representativa» (Paz Gago, 1999: 107-108).

${ }^{58}$ Cfr. Cuesta Abad (1997: 98).

${ }^{59}$ Cfr. Hassan (1984: 24-25).

${ }^{60}$ Cfr. Perloff (1981).
} 
tendencias líricas dominantes durante la primera década de nuestra posguerra ${ }^{61}$. Vinculada a este progresivo abandono de los significados estables, «la indeterminación que surgiría de las poéticas y de la poesía de los años 1960 y 1970 tendría un efecto mucho más abarcador y un vínculo más claro con varios fenómenos culturales, y se ligaría más estrechamente al concepto de la postmodernidad» (Debicki, 1997: 52).

La indeterminación resulta en la poética posmoderna de una aproximación a una realidad que desconfía de una representación lingüística sistemática y unitaria, de modo que ella contribuye a la diversidad de sus interpretaciones. Esta operación hermenéutica necesita de la expectativa de plurisignificación que el poema genera en sí mismo. En oposición a la perdurabilidad del signo poético moderno, la poesía plantea en la posmodernidad el acceso a la realidad desde una imprevisibilidad que emana de la misma construcción indeterminada del significado; de ahí que la capacidad de cuestionar el carácter logocéntrico del lenguaje aparezca en los textos poéticos ligada al proceso de relativización del significado: diversos poetas del 68 proponen un tipo de escritura basada en las múltiples sorpresas verbales del texto, a partir de discursos del sinsentido o de un significado imposible cuya intención sería reflejar la incomunicación como ideal poético.

Y es que, en las propuestas textuales más radicales y arriesgadas, el significado y toda su galaxia de sentidos, más que estar depositados en las palabras de los textos, aparecen en una fluencia que parece escapar más allá de toda comprensión ${ }^{62}$. Este tipo de poesía pretende no sólo transgredir el valor instrumental del signo lingüístico, sino también confundir al lector y sumirlo en una experiencia de recepción desconcertante mediante un lenguaje que renuncia a significarse: el poema tiende a manifestar así cómo se deshace el sentido de las palabras que lo componen como texto ${ }^{63}$. Y es que el problema del significado no es sólo una cuestión estética en la poética posmoderna, sino también un asunto de calado epistemológico, pues es convertido en el eje de la creación $^{64}$. De manera simultánea a su enunciación, el texto poético muestra unas claves de interpretación de carácter indeterminado, que son ofrecidas al lector como una tarea que debe completar. En efecto, la creación de unos textos cuyo sentido artístico reside en su capacidad de ambigüedad, necesita recurrir a unas tensiones semánticas nunca resueltas en la escritura del poema.

Como elementos retóricos generadores de ambigüedad, la ironía y la intertextualidad favorecen una dispersión semántica de gran intensidad en la poética posmoderna española. Ambas responden a la intención de subvertir los significados

\footnotetext{
${ }^{61}$ Cfr. Azancot (1971: 9).

${ }^{62}$ Cfr. Blesa (1998b: 135-158).

${ }^{63}$ Cfr. Paz Gago (1999: 246).

${ }^{64}$ Véase Betelloni (1997).
} 
artísticos de la tradición culta y de los mass media. En los poetas del 68, su uso se ha visto como un ejercicio de recreación vinculado al sarcasmo de una época al final de las culturas, y también como una crítica de los modelos poéticos sobre los que se realiza su reescritura o reinterpretación cultural. El valor paródico de tales procedimientos canaliza la descreencia del poeta posmoderno respecto a elementos de la tradición a los que desiste de defender o afirmar con el fervor del artista moderno. Cuestionada la capacidad del lenguaje para referir la realidad, la ironía y la intertextualidad son mecanismos retóricos que reniegan de la originalidad, al resonar irónicamente en ellos el eco de unas voces prestadas. Y, además, hilvanan el cañamazo expresivo de la poética posmoderna tendente a conformar el poema como una polifonía de escrituras que remiten a otras, creándose así no sólo una distancia insalvable entre autor y enunciador, sino también la ambigüedad de unos sentidos que el lector debe determinar.

Si tenemos en cuenta el relativismo que muestra esta generación ante los entusiasmos colectivos, la ironía sirve al poeta para marcar tanto la frialdad de la emoción personal como su parodia. Mediante la ironía, la poesía muestra una tendencia antisentimental y rechaza ser vehículo de su voz personal. La abrupta interrupción de la emotividad del poema asignada a la ironía tiene que ver más con la irrupción de una «ironía reveladora», afín a una práctica poética cognoscente de la realidad, que con una «ironía deformadora» que la menosprecia y la descoyunta grotescamente ${ }^{65}$. El efecto irónico, humorístico y hasta sarcástico procedente de los intertextos es un lugar común en la poesía posmoderna española inseparable de una actitud de pesimismo y desesperanza artística ${ }^{66}$. Esta recurrencia a modelos de la tradición suscita una relectura crítica de la cultura anterior, ya establecida como realidad, y constituye, a su vez, un ejercicio de reescritura donde el lenguaje del poema remite a un sistema de significaciones previamente establecido ${ }^{67}$. A través de su indeterminación, el diálogo con la historia del arte sirve a esta generación de estímulo para pervertir los sentidos de un tópico acomodado en la tradición. Este tipo de manipulación retórica tiende a desmitificar los loci que han abastecido el arte, y concita una desvinculación de los sentidos habituales atribuidos a estos emblemas, porque en la recreación del tópico quedan enfrentadas, disgregadas o deconstruidas significaciones habituales $\mathrm{y}$ concordadas culturalmente.

Desde esta perspectiva, no existe para los poetas del 68 un tema que adquiera por sí mismo, por su contenido o implicación sentimental, un valor poético que justifique su condición artística; así que cualquier tema resulta susceptible de ser abordado por la escritura. Si la escritura del poema es sólo una cuestión de estilo, queda claro que la

\footnotetext{
${ }^{65}$ Cfr. Prieto de Paula (1996: 112).

${ }^{66}$ Cfr. Bousoño (1980: 313-317).

${ }^{67}$ Cfr. Pérez Firmat (1978: 1-13).
} 
personalización retórica de un tópico almacenado a lo largo de la historia en cualquier composición tiene que ver con la destreza técnica del autor, y no con su originalidad. Debido al descrédito de la novedad y a la asunción de universales imaginativos en la posmodernidad, de temas y de géneros clásicos, la intertextualidad resulta imprescindible para afrontar una forma de escritura donde es su recreación personal lo que certifica su validez. Tanto la elección del motivo, en cuya reinterpretación particular sólo hallaría el poeta la posibilidad de ser original, como el uso de los elementos estilísticos que lo (dis)torsionan, constituyen la base de su creación poética. La renuncia a la búsqueda de nuevos temas conlleva un tipo de creación donde la reescritura estilística del motivo genera un cuestionamiento crítico en relación con la ideología que el tópico representa culturalmente: así ocurre con el bucolismo renacentista, el épico ideal militar, las ruinas, etc. De un modo intencionado, la polivalencia semántica o indeterminación confiere al viejo motivo elegido una formulación artística que debe contar con la cooperación del receptor, puesto que en el poema se revisan irónicamente las convenciones que rigen los planteamientos ideológicos y las expectativas de su lectura $^{68}$. Esta apropiación de los koinoi topoi tradicionales es significativa en la poética posmoderna española, ya que su tratamiento actualiza mecanismos críticos centrados en la relación entre la escritura y los modos de representar la realidad.

Por ello, el sistema culturalista dominante en la lírica del 68 asume como propio el recurso de indeterminación poética, al debilitar el valor referencial del mensaje literario mediante una consciente saturación de intertextos cultos o citas explícitas en el poema ${ }^{69}$. De un lado, la función expresiva queda diluida por intermediarios enunciativos o por modulaciones irónicas; de otro, cualquier referencia externa acaba perdiéndose en ese laberinto sin salida que constituye el lenguaje del poema. El tema poético es extraído de la tradición literaria y emerge explícitamente en forma de citas o de modulaciones estilísticas, cobrando importancia en su discurso poemático la polifonía textual con que la tradición lo ha tratado y su yuxtaposición fragmentaria. Se asiste, pues, a un diálogo intertextual de la literatura con la literatura misma según actitudes críticas que revisan la tradición y la inscripción ideológica de sus motivos. Los innumerables motivos literarios que componen el imaginario mítico se disponen en el poema para ser violentados, subvertidos o revitalizados, según la reinterpretación del tópico que hace el autor y por el resultado retórico-ideológico de su recreación. La reinterpretación de los

\footnotetext{
${ }^{68}$ Cfr. Kermode (1979: 91-112).

${ }^{69}$ Para Prieto de Paula, «no importa demasiado la particularización de las formas, muy variadas, en que puede actualizarse este sistema. Éstas van desde la concepción del poema como una cadena de citas de autores diversos y en lenguas extranjeras, a las continuas referencias culturales exógenas que funcionan como aperturas hacia otras zonas de interpretación no contenidas en los límites de la composición (y, en definitiva, como negación del sentido inequívoco); desde la creación poética sobre un soporte argumental ajeno y previo, al uso del monólogo dramático en boca de un personaje arrancado de la historia o de la ficción artística» (Prieto de Paula, 1996: 176).
} 
emblemas culturales origina, a partir de su ambigüedad e imprevisibilidad semántica, una indeterminación de sus significados convencionalmente aceptados. Esta capacidad no proviene sólo de la plurisignificación de las palabras del poema, sino que surge también de las múltiples posibilidades significativas que convoca su resonancia en la actividad de su recepción. Así, el fenómeno de una intertextualidad explícita o implícita aparece en distintos niveles de significación y funciona, en su voluntad de diálogo con la tradición, en un nuevo contexto textual donde el sentido original convive con otros contemporáneos.

Al recurso de la cita explícita o del uso del intertexto implícito, se podrían añadir dos elementos extremos de intertextualidad: el palimpsesto y el pastiche. Se trata de modos enunciativos consustanciales al carácter radical en la construcción indeterminada de los textos poéticos. Concebidos desde la incertidumbre semántica que proporciona el ensamblaje de materiales dispersos confluentes en el poema, éstos intentan contravenir la codificación tópica como una manera de enfrentarse a su instrumentalización convencional. No por casualidad la evolución de la poesía posmoderna tiende a reflejar el proceso de absolutización del lenguaje como una experiencia fundacional o primigenia. $Y$, aunque no sea más que un discurso entre otros, la poesía busca ser ese lugar del lenguaje instaurado como origen creativo, expulsando de su seno toda virtualidad de representación o mimetización de otros lenguajes. En suma, tales procedimientos de reescritura no sólo muestran el fracaso de la originalidad, sino que en ellos se abordan las conflictivas formulaciones de la escritura y de la identidad del sujeto como nociones producidas, asimismo, por el lenguaje: «arranca así la crisis del sujeto que llega a su culminación en el pensamiento postmoderno actual, y arranca precisamente en la reflexión sobre el discurso lírico [...] que deja de considerarse como expresión de la subjetividad para concebirse en términos de representación de la alteridad, del sujeto en tanto que alteridad»(Paz Gago, 1999: 91-92). Reducir a una particularidad formal la presencia individual del poeta en el conjunto de interpretaciones que ese lugar común ha manifestado en la colonización de sucesivos autores a lo largo de la historia cultural, es un modo de cuestionar la identidad del autor y de poner en apuros al sujeto moderno como entidad real que aparece inserta en la voz del poema.

\section{La kenofilia poética (o el vacío ontológico de los signos)}

En estrecha relación con los procedimientos anteriores, la poesía posmoderna española desarrolla una peculiar tendencia temática a expresar el vacío como paradójico origen de la palabra poética. Para la lírica sesentayochista, el acto de escritura implica un acontecimiento de indagación, conocimiento y experiencia de lo poético mediante un proceso de esencialidad expresiva que encuentra en el silencio una metafórica «muerte» 
del signo. Las razones que explican esta dimensión de lo poético en los autores del 68 tendrían que ver con esas «dudas ilustradas sobre la providencia» que dan paso a una inusual operación retórico-textual de «estabilización en el vacío» (Prieto de Paula, 1996: 120). Este particular modo de kenofilia poética asume una emanación lírica cuyos recursos enunciativos tienden a negar el lenguaje. La escritura del poema se sustenta en una negación de la palabra y en un proceso de des-significación, como modos predilectos de adentrarse en la sustancia poética: más que atender a las relaciones sintagmáticas y paradigmáticas de los elementos lingüísticos que componen el texto, el poema incide en los huecos del signo, en lo que el lenguaje no puede decir del mundo. El poema canaliza un tipo de experiencia donde el advenimiento originario de lo poético conduce a un resultado inverso: revelar no tanto la representación de un objeto en ausencia cuanto la presencia de su vacío referencial. Diferida del signo convencional, la palabra poética se convierte en la figuración de un eco que tiende a buscar la huella de su origen en su propia autorreferencialidad. A este respecto, ya consideraba Paul de Man que la lírica, más que ser conciencia de algo ausente, constituye una «presencia de la nada, de un vacío al que incansablemente da nombre el lenguaje poético» (Cuesta Abad, 1997: 79). Si la convergencia de significante y significado en el signo convencional hace posible la representación del mundo, de la idea o del sujeto, esta misma relación es, en la poesía posmoderna, una iluminación de su divergencia. Esta radical negación del lugar del lenguaje en la poesía posmoderna es acorde a su radical experiencia de vacío ontológico y a su peculiar vivencia de la muerte ${ }^{70}$.

La orientación metapoética de la lírica del 68, como ejercicio autocrítico, responde a esa retórica expresiva del vacío y a los modos de «decir nada». Para esta poética, si el poema es un signo de vacío, la poesía es una conmemoración del silencio: se desconfía así del orden metafísico de la palabra y se cuestiona la noción (burguesa) de discurso. Al hilo de aquella modernidad poética que fundaba su pensamiento en la alteridad, la poesía posmoderna necesita criticar al lenguaje para desasirse de lo convencional y acceder a una esencialidad verbal primigenia. No en vano, a principios de los años ochenta, la «retórica del silencio» tiende a desmontar en su discurso los códigos heredados de la tradición, ya que el texto señala que su experiencia de lenguaje procede de los huecos, de lo indecible ${ }^{71}$. No es casual que la tendencia a mostrar este vacío constituya un ideal subyacente a la experiencia artística posmoderna. El resultado de esta indagación es una conmovedora experiencia nihilista del lenguaje en relación

\footnotetext{
${ }^{70}$ Cfr. Agamben (1982: 105-126). Para este autor, la poesía vendría a ser una especie de dimensión límite del lenguaje y de la significación, el punto en el cual el lenguaje deja de significar la res sin convertirse en una cosa entre las otras, porque, como puro nombre y pura voz, apunta a sí misma. Así, el poeta experimenta en la escritura un hablar a partir de la nada que se representa por un movimiento que ni va a ninguna parte ni está en ningún lugar.

${ }^{71}$ Parafraseamos los versos de Jenaro Talens: «Y así, dictado por los huecos, / lo indecible se anuncia» (Talens, 1980: 14).
} 
con el mundo. La kenofilia poética presenta, pues, el silencio o el blanco de la página como ámbitos pertinentes donde marcar esta distancia insalvable entre la experiencia de vida y la imposibilidad de su representación en el poema.

En efecto, a la primera etapa lírica del 68, caracterizada un tipo de poesía cuya representación se torna simulacro de realidad, sucede una segunda donde la escritura del poema se repliega sobre sí misma para ser cada vez más renuente a los efectos de una transitividad referencial. De una poesía basada en redundancias y amplificaciones verbales, se pasa a otra cuya arquitectura textual tiende a una condensación retórica extrema, «área de máxima tensión del lenguaje, que es la zona en cierto modo pre-verbal o supra-verbal, el área de lo no dicho y quizá no decible» (Gimferrer, 1988b: 121). No obstante, ambos modos de escritura ofrecen una reflexión retórica común en torno al vacío subyacente a la experiencia poética, si bien ésta se desarrolla según estilos distintos: mientras el culturalismo y el irracionalismo exhiben una ornamentación verbal que trata de maquillar con las palabras el vacío del lenguaje, la denominada «retórica del silencio» asume ese vacío como un ideal estético. Una vez cumplida y agotada la exuberancia culturalista de la primera época, los autores del 68 se deslizan hacia una lírica cuya creación es también una labor sistemática de interrogación que constata la inanidad del lenguaje. La evidente ruptura entre poema y realidad, así como la incapacidad de la palabra para referirla aparecen como nociones estéticas que postulan una huida por los resquicios del lenguaje, experiencia de lenguaje cuya plenitud en el vacío descubre sus insuficiencias. Esta (barroca) insistencia en el vacío de las representaciones, en su naturaleza de simulacro, desmitifica la noción de «centro» para el lenguaje: la poesía posmoderna erige esta ausencia de mundo en el punto de partida de un discurso lírico que ha de dotarse de una plenitud semántica nacida de la indeterminación e, incluso, de la vaciedad del sentido mismo ${ }^{72}$.

Según ha observado Prieto de Paula, el acceso poético por esta vía de ausencia sería consecuencia también de una marcada conducta estética que acaba afectando a las relaciones que el poeta establece entre arte y vida ${ }^{73}$. Se trata de ciertas actitudes ante el arte que encuentran en la kenofilia poética un medio de expresión adecuado. La denominada por el citado crítico «reserva sentimental» implica una distancia entre poeta y sujeto poético que suele manifestarse como una zona de indeterminación que apunta al vacío. Aunque esta distancia no suele adoptar una formulación retórica fija, la compleja conexión entre el autor y el yo poemático se caracteriza mayoritariamente por una radical falta de asentimiento, observable incluso cuando el poema simula su coincidencia. Este prejuicio antisentimental, provocado por este radical nihilismo de la

\footnotetext{
${ }^{72}$ Cfr. Cuesta Abad (1997: 127).

${ }^{73}$ Cfr. Prieto de Paula (1996: 103-130).
} 
experiencia poética de que hablamos, acaba cercenando cualquier contagio de emotividad. La inmediatez sentimental resulta del todo imposible ante la inserción de elementos antipoéticos en el tema o en el mensaje, las interrupciones humorísticas o metapoéticas que actúan de freno o de tamiz irónico, pues «entre poeta y motivo del poema se interpone un sistema de filtros que hace decrecer su vinculación afectiva» (Prieto de Paula, 1996: 107-108). Con ello, deja de creerse en la correspondencia entre una verdad vital y otra poética surgida del mero trasvase referencial, ya sea éste biográfico o ideológico. $\mathrm{Y}$ es que, llevados por una particular desesperanza cognoscitiva, estos autores ven en la ficción poética un modo de deshacer, cuando no de negar radicalmente, la identidad del emisor con el sujeto poemático mediante múltiples recursos de diseminación y fragmentación de la voz lírica ${ }^{74}$. El artificio literario articula un distanciamiento que, aun produciendo algún efecto de empatía y de identificación, reconoce su naturaleza fingida. No en vano, su plasmación en el poema retoma las complejidades de una enunciación lírica cuyo estatuto ontológico remite a la condición textual del sujeto y nunca a su relación directa con el mundo o los sentimientos.

Paz Gago señala que teorizar sobre la fuente de la enunciación lírica es un tema especialmente controvertido en relación con el género poético, por cuanto esta instancia constituye en él una inespecificidad, pues es en sí misma un elemento de indeterminación. Desentrañar tal problemática resulta incluso más conflictivo en la poesía contemporánea, debido a que en ella crea intencionalmente la ficcionalización de la fuente enunciativa, su desdoblamiento o su disgregación en modelos dialógicos o monológicos ${ }^{75}$. En la poesía sesentayochista, lo común es la aparición de un yo retórico cuya presencia textual abre un controvertido eje de enunciación, acorde con una radical conciencia del estatuto ficcional de la lírica ${ }^{76}$. La caracterización retórica del sujeto, es decir, su concepción como producto del lenguaje, pone en evidencia el problema tradicional de su unidad, pero también el de su identidad en el proceso de una ficcionalización subjetiva. Lejos de expresarse como un sujeto constituido, éste siempre se crea y se renueva en el espacio del poema, fuera del cual deja de existir: «el sujeto lírico no existe, sólo se crea» (Combe, 1996: 153). Así, la superposición del plano artístico sobre el plano real se dispone fragmentariamente mediante máscaras (simulacro de un sujeto) obtenidas a partir de correlatos históricos o escenificaciones teatralizadas que marcan una distancia entre el texto, el poeta y el mundo. La poética posmoderna se sirve y explota esta dificultad de definir la lírica desde su fuente enunciativa, en virtud tanto de su considerable variabilidad histórica como de la inespecificidad del yo que enuncia: el poema suscita un espacio enunciativo caracterizado por la difusión del

\footnotetext{
${ }^{74} \mathrm{Al}$ respecto, véase Ferrari et al. (1994).

${ }^{75}$ Cfr. Paz Gago (1999: 99-100).

${ }^{76}$ Acerca de la noción de «sujeto retórico», véase Combe (1996: 127-153).
} 
origen de un discurso que verbalmente emerge de la nada o se presenta autosuficiente y autorreferencial $^{77}$.

Ya hemos señalado que la metapoesía genera una reflexión sobre la incapacidad del lenguaje para reproducir la realidad y las experiencias vitales. Precisamente la poesía posmoderna española hace explícita esta temática de la ruptura con lo representado a partir del vacío de la palabra. En este sentido, el poema no sólo resulta un modo truncado de referirse al mundo, sino que, como expresión de una ausencia del objeto, la voz misma del poema -el lugar desde donde nace el enunciado lírico- sólo podrá determinarse en una naturaleza verbal que remite al vacío de su referencia. En palabras de Laura Scarano, «inscrito en una línea estética de corte posmoderno, el arte sólo puede predicar una ausencia; la creación del poema significa la destrucción de la realidad que le dio origen» (Scarano, 1991: 324). La insistencia en una retórica negativa conlleva un renovado desgaste de la noción moderna de sujeto y de los rasgos ideales de su perdurabilidad en la creación. La experiencia individual que el poema parece trasmitir no refleja más que una ficción de la que el sujeto también forma parte: cuestionada la voz (personal) del sujeto en los estratos de lenguaje que componen el poema, éste es expresión de la vacuidad y del carácter esquizofrénico de un sujeto, tras el que resuenan otras voces ${ }^{78}$. Si el rechazo a ostentar el yo era parte del proceso de su relativización en los autores del medio siglo, el recato a presentarlo directamente evidencia, en los del 68, que la relación del poeta con el texto, que tiende a ser problemática, es reflejo de esa otra brecha insalvable entre identidad y discurso ${ }^{79}$. En opinión de Prieto de Paula, «dicha relación puede ir desde la confusión de uno y otra en una sola realidad psíquica (el poeta es el que nos habla de él, sin intermediaciones ni filtros) a la consideración de esa primera persona del poema como un ser que nada tiene que ver con el creador, por más que gramaticalmente lo suplante. Muchas veces no hay dificultad alguna en el discernimiento de esta conexión, pues el título, el tono o determinadas claves aquilatan, en fin, cuál es la situación. Otras veces la ambigüedad no tiene aclaración al constituirse ella misma en centro del sistema creativo» (Prieto de Paula, 1996: 332-333). En definitiva, en cuanto implica una reflexión formal sobre la naturaleza del artificio poético, la poética posmoderna sitúa como eje de su elaboración la erradicación de una identidad poética mediante una «autoficción del yo» ${ }^{80}$.

De igual modo, el «existencialismo negativo» de la generación del 68 se corresponde con actitudes derivadas de un intenso nihilismo en la esperanza cognoscitiva, y actualiza los postulados vitales del desengaño barroco y del

\footnotetext{
${ }^{77}$ Cfr. Pozuelo Yvancos (1998: 54-55).

${ }^{78}$ Véase Cañas (1989: 52-53).

${ }^{79}$ Cfr. Stierle (1997: 203-268).

${ }^{80}$ Cfr. Lanz Rivera (2000: 573).
} 
escepticismo crítico acerca de la razón, y propone de conductas que extraen de la derrota y del desasimiento una renovadora lección estética ${ }^{81}$ : el fervor o la afirmación vital que incita a la composición del poema termina siendo una reflexión sobre el vacío que subyace a la propia existencia. El poema es así un espacio textual cuya experiencia de lenguaje asume el fracaso de cualquier mediación simbólica ante la vida. Este resultado del lenguaje con la realidad refleja la descreencia en los vínculos entre el mundo y las palabras: esta falta de convicción desmarca a estos autores de aquellas utopías de salvación que habían definido la poesía en momentos anteriores. Esta insistencia en los límites del lenguaje para hablar de la realidad implica saber que la aprehensión lingüística del mundo se realiza por medio de lo que sólo éste es capaz de mostrar de él, de modo que las palabras favorecen la comprensión de aquello para lo que sólo el lenguaje dispone de nombre. Se produce así una paradoja entre la necesidad que el poeta tiene de nombrar (o fundar) el mundo y la imposibilidad de poder hacerlo fuera de sus elementos verbales.

La transferencia de sentido de la palabra genera una ilusión de conocimiento de las cosas que el poeta cercena cínicamente, al demostrar en el transcurso de la composición lo contrario, ya que toda experiencia de realidad que el poema pudiera contener procede del sujeto mismo que piensa con el lenguaje. La certeza de esta ruptura irreconciliable con el mundo confiere al poema una extrema conciencia de vacío $^{82}$. En su conjunto, la poesía del 68 elabora un proceso de despojamiento retórico que conduce a un cuestionamiento de la referencia y, de manera paralela, señala un lugar «en que la deixis apunta a la nada como realidad inconmovible» (Prieto de Paula, 1996: 124). La quiebra del racionalismo es causa de la mirada distante del poeta en relación con la escritura y del convencimiento de que su actividad, antes que ejercicio de conocimiento del mundo, sea una redundancia tautológica que se cierra sobre sí misma. Esta imposibilidad de acceder desde las palabras a la realidad concita un rechazo de los valores lógicos e instrumentales del lenguaje y propone una retracción al origen de la materia poética: el poema no señala al mundo, sino que resulta de un intenso proceso de búsqueda que tiende a identificarse con su realidad verbal ${ }^{83}$. El poema es el rastro de un itinerario hermético cuya representación simbólica más frecuente (circular o laberíntica) confiere una apariencia de salida falsa al mundo, ya que lo único que marca es su inaccesibilidad. Este tipo de poesía, como experiencia de lenguaje que se justifica a sí desde él mismo, promueve el hallazgo de formas y de reflexiones que indagan en su desvinculación de las cosas.

\footnotetext{
${ }^{81}$ Sobre este término, cfr. Prieto de Paula (1996: 119).

${ }^{82}$ Así lo explicitan los versos del poema «Ostende», de Guillermo Carnero, en Ensayo de una teoría de la visión, 1977): «producir un discurso / ya no es signo de vida, es la prueba mejor / de su terminación. / En el vacío / no se engendra discurso, / pero sí en la conciencia del vacío» (apud López, ed., 1998: 284).

${ }^{83}$ Cfr. Olivio Jiménez (1985: 17).
} 
Para Juan José Lanz, esta orientación de la lírica hacia lo esencial marca la evolución del culturalismo e irracionalismo, como primeros rasgos estéticos generacionales, para llegar a una poesía fragmentaria cuyo acceso a lo real contradice la totalidad (ideal) del sistema. En ella el poeta prescinde de toda apoyatura anecdótica, elimina elementos superfluos y su escritura tiende al silencio, de modo que la palabra se propone como único sustento de realidad ${ }^{84}$. Incluso los poetas ideológicamente cercanos al realismo, cuyas obras proponían una alternativa lírica a las formulaciones esteticistas de los novísimos, cultivan una poesía dialéctica cuya adecuación entre la realidad circundante y el lenguaje poético asume una depuración expresiva acorde a lo fragmentario; aquí, la contención y el afán de precisión trasladan a la composición un orden cerrado que no se corresponde con el discurso del realismo tradicional: la crítica al código mediante un proceso de depuración lingüística previo en Agustín Delgado o José-Miguél Ullán confirma en sus textos que la mención de la realidad es revelación de la misma fuera de sus estereotipos ideológicos ${ }^{85}$.

La evolución generalizada del 68 durante la década de los setenta advierte que el objeto poético apenas encuentra representación en un lenguaje que no se oriente al silencio $^{86}$. En este nuevo contexto estético, lo que tiende a reflejar el discurso del poema es una experiencia lingüística cuyo referente se identifica con el vacío; que el signo lingüístico no signifique nada exterior a sí mismo implica proponer una poética que apunta de un modo acuciante a su negación ontológica. Si desde Mallarmé la poesía intentaba conseguir el estatuto ontológico del objeto natural, en la poética posmoderna la realización de este anhelo sólo puede manifestar su imposibilidad, pues la palabra representa el vacío del objeto, ausencia opuesta a la plenitud física del mundo que no necesita de los signos para significar.

\section{Resemantización del tópico muerte como escritura}

Junto a la kenofilia, la poética posmoderna española desarrolla una resemantización del tópico «muerte», como metáfora que refiere adecuadamente la naturaleza del signo poético y de su escritura. La asunción de este topos clásico condensa la noción artificial del símbolo, en tanto que signo carente de vida por el que se expresa la finitud humana ${ }^{87}$. Al conjunto de significados que este motivo ha mostrado a lo largo de la tradición artística ${ }^{88}$, se añade en la lírica contemporánea española la representación desvitalizada de lo poético. Podríamos decir que la escritura poética, con

\footnotetext{
${ }^{84}$ Cfr. Lanz Rivera (2000: 589-590).

${ }^{85}$ Cfr. Molinero (1983: 17).

${ }^{86}$ Cfr. Sepúlveda-Pulvirenti (1990) y Blesa (1998a).

${ }^{87}$ Cfr. Baudrillard (1980).

${ }^{88}$ Cfr. Curtius (1995: I, 122-127) y Huizinga (1972: 194-212).
} 
la intención o no de perdurar, es un acto que plasma la muerte metonímica del sujeto que escribe: las palabras tienen el vacío como referente y el poema refleja la experiencia de finitud del sujeto $^{89}$. Tal resemantización favorece un prisma cognoscitivo cuyo pesimismo lo acerca a esa barroca lección de la nada que obtura la redención, consolación o salvación como finalidades atribuidas al arte. La noción de escritura como «muerte» repercute en el deseo contemporáneo de permanencia del artista en la obra, de modo que éste aparece ahora como reclamo inútil y fracasado de antemano. La muerte aplicada al símbolo advierte no sólo de la ficción simulada del mundo que lleva a cabo la escritura, sino también de la índole relativa y finita de sus significados ${ }^{90}$.

Queda así invertido irónicamente en la posmodernidad el tópico horaciano que, desde la Antigüedad, consideraba la poesía como un monumento aere perennius, más duradero que el bronce, que resguarda la memoria del autor contra los embates del tiempo. Por el contrario, el poema es un fingimiento de vida: su recuerdo es una experiencia que necesita del lenguaje y su escritura no elude la reflexión sobre su condición ficcional. Esta desolada afirmación del vacío de la palabra en relación con la vida dentro de la poética posmoderna española se abastece de elementos de la tradición: la vanitas clásica o el taedium vitce modernista reflejan esa radical toma de conciencia ante una escritura encargada de trazar inútilmente signos que sólo significan muerte. Este desasimiento poético revela al poeta la verdad de las cosas y de su existencia, instancia oculta al simple conocimiento discursivo e instrumental de las palabras. Esta orientación en la resemantización del tópico conlleva una desposesión radical del lenguaje mediante la que el poeta obtiene una renovada experiencia del mundo y su materia $^{91}$.

Pero antes de analizar las repercusiones estéticas de esta resemantización en la poética posmoderna española, hagamos un recorrido por las significaciones culturales que este tópico ha manifestado a lo largo de nuestra literatura. En la época medieval, éste presenta ya dos modos antitéticos, aunque complementarios, de figuración simbólica: por un lado, la literatura concibe la muerte como elemento necesario para liberar el alma humana del mundo, siguiendo los postulados religiosos y, por otro, en la vertiente pagana, éste se describe como un personaje macabro ante cuya llamada el ser humano pierde todo placer terrenal ${ }^{92}$. Ambas son plasmaciones de un ars moriendi en el

\footnotetext{
${ }^{89}$ Véase Jiménez (1972: 375-389).

${ }^{90}$ Cfr. De Man (1971: 36-50).

${ }^{91}$ Cfr. Mas (1986: 53-63).

92 En la primera vertiente, se observa la incidencia de la vanitas procedente del Eclesiastés y mediada por la patrística, que refleja la labilidad del mundo introducida por Boecio (s. V) en De consolatione philosophice. Amediados del siglo XII, el poema latino del monje Bernardo de Morlay consigna uno de sus tópicos: la interrogación latina del ubi sunt, y, partiendo de ella, Inocencio III establecía el tópico menosprecio del mundo en su De contemptu mundi (s. XIII), núcleo de la predicación religiosa que declaraba al mundo enemigo del alma y concebía la muerte como liberadora para la verdadera vida. Estos
} 
que confluyen elementos alegóricos de las tradiciones culta y popular. Tales orientaciones tienen en la cultura medieval un marcado carácter abstracto, aunque a lo largo del siglo XIV alcanzarán una progresiva personalización. Las Coplas de Manrique, hito en la transmisión y codificación del tópico en nuestra tradición literaria, son un ejemplo notable de este cambio en la significación del motivo ${ }^{93}$. La metáfora «fluvial», expresada ya por Heráclito, adquiere un valor personal en el poeta castellano: el advenimiento de la muerte es sentido como un proceso lento, pero inexorable, por el que la vida se fuga de continuo. La pérdida irreparable de Don Rodrigo intenta compensarse además con su fama, de modo que el que «la vida perdió» permanezca en la memoria perdurable de sus obras, fijadas en el monumento que intenta ser la elegía manriqueña ${ }^{94}$. Tras éste, será Quevedo quien logre reunir en su poesía todas las variaciones precedentes del tópico, y proyectar en él la renovada hondura metafísica y escatológica de su decir poético ${ }^{95}$. Desde la Antigüedad Clásica, los aspectos elegíacos o hedonistas del tópico convivirán a lo largo de la cultura medieval, renacentista y barroca, hasta cristalizar en temas y géneros dependientes del mismo (memento mori, carpe diem, meditatio mortis, ubi sunt, las ruinas, la elegía, el panegírico). Tales núcleos manifiestan una actividad artística sustentada en una reflexión acerca de la existencia humana, que no puede disociarse de una cosmovisión religiosa y cultural. En ella se ha de reconocer la reiteración de lugares comunes universales: el lamento por la fugacidad de la vida, la desaparición física o el proceso de transformación orgánico-material, tan frecuente en la plástica y en la poética escatológica barroca.

Mayor interés despierta la evolución del tópico tras la impronta romántica: a partir de la lectura que Schiller realiza de la máxima latina Et in Arcadia ego, compendio de una larga elaboración que va de los clásicos Polibio, Ovidio y Virgilio al renacentista Sannazzaro, el significado del motivo abre a sus sentidos tradicionales una variante

motivos son observables en la literatura castellana desde la Edad Media al Barroco. Respecto a la segunda, la consolidación de la burguesía y el establecimiento de un mundo más cómodo como fuente de placer que satisface los instintos del hombre, promueve en la cultura de los siglos XIV-XV una protesta contra la muerte, convertida en personaje funesto y truculento. De salvadora a verdugo: ése es el sentido de la recriminación del «planto» del Arcipreste de Hita o del que Fernando de Rojas pone en boca de Pleberio.

${ }^{93}$ Cfr. Alda Tesán, ed. (1985). El poeta discrimina entre las tres vidas (dos en la tierra y una en el cielo) que pasan desde Boecio a la cultura medieval. Las dos primeras proceden del Somnium Scipionis ciceroniano, donde la inmortalidad es un galardón otorgado a los seres nobles que se han sacrificado en el servicio a la patria. Manrique rompe el esquematismo impersonal y se aproxima a la proyección horaciana de lo inmortal, al magnificar en el monumento a su padre, que es su obra, un orgulloso sentido de la vida. En las Coplas aparecen suficientes elementos originales en torno al tópico que será objeto de revisita de poetas españoles posteriores. Por su parte, Américo Castro señala que una contribución importante en relación con dicho tópico es la imagen de una «muerte bella», ya que ésta es un ente inmaterial que no coincide con el repulsivo personaje medieval. En Manrique, la muerte no presenta rasgos simbólicos de alguien que viene a matar al hombre, sino que es éste quien realiza la acción de morirse (cfr. Castro, 1957: 51-57).

${ }^{94}$ Cfr. Lida de Malkiel (1952).

${ }^{95}$ Cfr. Zavala (1965: 41-60) y Roig del Campo (1967: 79-101). 
estética que lo sitúa ante su renovadora comprensión moderna; esto es, lo hace asomar a la dimensión irónica de la experiencia de finitud del sujeto romántico. Precisamente la temporalidad que desea abolir el arte colma de contenidos elegíacos a la poesía romántica, «pues la experiencia temporal es el contenido de la conciencia poética que toma forma en la elegía bajo el aspecto de una resignación» (Cuesta Abad, 1997: 55). Esta resignación schilleriana constituye una especie de «ironía elegíaca» donde la expresión denota lo temporal, pero connota la negación de la temporalidad. Frente a sus formulaciones clásicas, la poesía romántica afronta la constatación de la muerte en una reiteración enclaustrada de los contenidos subjetivos, cuyo valor simbólico se basa en pulsiones negativas que reflejan el afán del sujeto por resguardarse de la temporalidad. A partir de aquí, el tópico pasaría a ser expresado mediante las «figuras de la ausencia» que tienen como objeto hacer presente lo ausente ante el lector. Según Paul de Man, al intentar liberar al sujeto de lo contingente y material, la escritura origina una perpetua huida hacia la alteridad, solución moderna a la desaparición física del sujeto ${ }^{96}$. La poesía romántica promovía así una afirmación nihilista como manifestación de una trascendencia vacía, sobre cuyas coordenadas avanzará la reflexión metapoética de la modernidad. Así, «por grandes que hayan sido (que lo son) los productos de este idealismo irónico, su fundación no deja de comunicar una experiencia sombría, puesto que el anhelo del ideal poético parece exigir un pacto mefistofélico, o una muerte en vida de la obra como forma determinada, o un sustraerse a la finitud mediante un simulacro suicida» (Cuesta Abad: 1997: 72). De este modo, la historia de las formas artísticas sería una historia de la temporalidad que culmina en la autoconciencia moderna de la muerte como significado central de todo símbolo poético, en el que aparece entrañada.

Ejemplo de esta alteridad ausente en la lírica romántica es la consideración del paisaje, procedente de la tradición dieciochesca como ámbito moral preexistente o espacio donde el poeta se integra. Su descripción romántica retoma figuraciones simbólicas que remiten a la puesta en escena de una ausencia, desaparición o disolución mediante la tensión entre lo limitado y lo ilimitado que, como trasunto de lo material y espiritual, dinamiza la relación del espíritu inmortal del hombre con la naturaleza. Se realiza así la encarnación de un paisaje solidario con los movimientos espirituales del yo lírico. El bosque es una alegoría de la soledad que proyecta la intimidad del poeta, cerrada en sí misma hacia lo lejano e infinito, o la afirmación de su individualidad al margen de los demás. Esta forma de alteridad ausente se expresa con otros espacios imaginarios aledaños al tópico (cementerio rural, sepulcros) que la lírica romántica expresa como trasunto anímico del poeta: este cultivo de paisajes y tumbas suscita una

\footnotetext{
${ }^{96}$ Cfr. De Man (1984: 13-14).
} 
«poética de los muertos» como cronotopo textual que define al tópico en el romanticismo ${ }^{97}$.

Sobre la base estética anterior, la progresión semántica del tópico «muerte» adquiere un impulso renovador en el Simbolismo, al verse el sujeto impelido a una retracción que desea su neutralización en el devenir inexorable del tiempo. La poesía de Baudelaire enmarca el motivo de la muerte en un lugar diferente a la naturaleza (paisaje) romántica: la Arcadia romántica se transforma en el paisaje urbano parisino. La «torre de marfil» es donde el poeta se recluye y automargina del mundo: el resultado ofrece una subjetividad omnicomprensiva, autosuficiente y ucrónica. Frente al panteísmo romántico, las imágenes del poeta son una adaptación moderna del lenguaje anagógico profanado aquí por un novedoso contexto de refugio doméstico, en que queda expresado el ideal del aislamiento de un sujeto que sueña con detener el tiempo ${ }^{98}$. En la poética simbolista, el paisaje representa una vivencia intensa del presentimiento de la muerte, al que habría de unirse una revelación metafísica de la existencia humana que alcanza su correlato en el lenguaje. Precisamente la persecución del ideal de eternidad en la belleza, y el resultado intuido de su fracaso, influyen poderosamente en la estética decadente del Modernismo hispánico. En Juan Ramón Jiménez y Antonio Machado, la significación del tópico se vincularía a una revelación de belleza, en cuya experiencia efímera reside la vivencia de lo trascendente. Se trata de una honda prospección subjetiva y espiritual, supremacía interior del poeta asociada a una proyección anímica y estética de melancolía, tristeza o solipsismo, y opuesta a la vulgaridad del mundo exterior. El poeta simbolista experimenta una sensación mortecina en consonancia con sus emociones internas, de modo que el motivo de la «ciudad muerta» habría de constituir un símbolo de irradiación espiritual nacida de este desarraigo vital del artista. En estos poetas, el tópico de la muerte articula una indagación metafísica de la existencia y de su temporalidad, cuyos símbolos remiten a la perdurabilidad.

Si la primera etapa juanramoniana está atravesada por la íntima e infinita nostalgia debida al destierro celestial -el poeta descielado-, lo que se resuelve en un lirismo decadentista que apunta «hacia lo que no se ve», su segunda etapa se caracteriza por un profundo anhelo de eternidad ${ }^{99}$. Sus Rimas (1902) constituyen una escritura que, en clave becqueriana, se correspondería con el análisis introspectivo de la tristeza a través

\footnotetext{
${ }^{97}$ Cfr. Fernández (1994: 82-83).

98 En el poema de Baudelaire «Paysage», puede leerse: «Les deux mains au menton, du haut de ma mansarde, / Je verrai l'atelier qui chante et qui bavarde; / Les tuyaux, les clochers. Ces mâts de la cité, / Et les grands ciels qui fint rêver d'éternité» [«El mentón en las manos, desde mi alta buhardilla, / Observaré el taller que canta y que platica; / Chimeneas y torres, esos mástiles cívicos, / Y los cielos que invitan a soñar con lo eterno» (Baudelaire, 1857: 179, vv. 5-10).

${ }^{99}$ Cfr. Jiménez (1989: 22-23).
} 
de miradas alternativas hacia el exterior y el interior del poeta. De la exterioridad, éste presiente un algo misterioso en las cosas que nunca acierta a definir, aunque la única realidad que esconden es la certeza de la muerte: habitante omnipresente del mundo que transmuta a los ojos del poeta los jardines en cementerios, el amor en un arrebato inútil o la aldea en un sepulcro melancólico. La muerte es compañera inseparable del poeta, que le lleva a «estar con los ojos abiertos a la nada» (Jiménez, 1989: 24). También en Antonio Machado la muerte infunde a algunos de sus poemas un singular efecto simbólico de desvelamiento: su experiencia de finitud se elabora mediante construcciones simbólicas bisémicas a partir de elementos de la naturaleza transformados en correlatos subjetivos y en presagios de la misma ${ }^{100}$. Con posterioridad, la poesía del 27 desarrollará una orientación existencial del tópico: la muerte adquiere en César Vallejo, García Lorca o Miguel Hernández connotaciones trágicas cuyo imaginario recurre a símbolos elementales. En Vallejo, la obsesión por la finitud responde a una formulación expresionista de desamparo y de angustia vital mediante algunos símbolos de oquedad ${ }^{101}$; en García Lorca, la muerte es símbolo esencial del destino trágico (fatum) a partir de figuraciones líricas en forma de conmovedores presagios. En Hernández, este motivo se vincula con símbolos telúricos de intensidad trágica.

En la segunda mitad del siglo XX, la asunción de la crisis del lenguaje en la poesía comporta una progresiva desmitificación de las convenciones literarias y una desintegración del sujeto en la creación literaria. Reconocida la fractura entre palabra y mundo, la poesía comienza a cuestionar la naturaleza perdurable del símbolo y sus signos de permanencia. Si el lenguaje manifiesta en la posmodernidad una representación discontinua de la realidad, el símbolo acoge un tipo de conocimiento inestable, al no poder configurar adecuadamente lo externo: el medio protector del lenguaje es un ámbito precario compuesto de signos cuyo valor resulta provisional y donde el sujeto no puede edificar su consistencia. La expresión de este vacío ontológico para la escritura, en los términos de una no-significación, asumirá el tópico con que se ha expresado la finitud humana. La comprensión del fenómeno poético contemporáneo reflejaría esta experiencia radical de la escritura, ya que «el paralelismo entre la conciencia de la palabra poética y la experiencia existencial de la muerte entreabre el cálculo posible sobre el espacio del significado esencial. El sentimiento de la muerte, intuición infranqueable desde la existencia, encierra el mismo mecanismo paradójico que el significado poético, entrevisto sólo desde la densidad de las significaciones objetivas del lenguaje» (García Berrio, 1994: 281). Maurice Blanchot identificó la escritura del poema con la experiencia de muerte que el poeta acomete mediante un

\footnotetext{
${ }^{100}$ Cfr. Aguirre (1973: 181-187).

${ }^{101}$ Cfr. García (2001: 144-152).
} 
sistema que apunta a lo inasequible y exterior a sí mismo: el destino del poema sería quebrar el cerco de la identidad y entregarse a la pasión de lo distinto, lo diferente, del otro absoluto. Esta entrega a la alteridad implica el emplazamiento de un afuera como exclusión necesaria del poder del texto, cuya conciencia es expresada «en los términos negativos del vacío, como horror y como muerte» (García Berrio, 1994: 289).

Si la poética posmoderna española confiere a la creación la posibilidad de una experiencia de alteridad en el lenguaje que sólo puede darse como negación, la resemantización de este tópico ase aplica a liberar la palabra poética del código, al querer situar su sentido al margen de la convención. La poética posmoderna expresa desde el interior del poema las trampas de un lenguaje hecho, la falacia de las representaciones o la incapacidad del símbolo para adquirir la consistencia de su referente. El significado del tópico vendría a significar, pues, este alcance y límite de la palabra poética.

La poesía de Gil de Biedma y de José Ángel Valente atiende a esta novedosa orientación metapoética del motivo, mediante la disolución del sujeto en el proceso de la escritura. En Gil de Biedma, la apariencia teatral de la disolución del sujeto (su muerte) a partir de una elaboración escenográfica del lenguaje conlleva la destrucción del propio objeto «poesía» ${ }^{102}$. De igual modo, Valente hace de la muerte un núcleo señalado de su poesía. La inclusión frecuente del tema en sus primeras obras se relaciona con la incertidumbre de la condición humana que, como realidad física o moral del individuo, adquiere un valor de oposición a la vida. Pero más allá de este sentido, la muerte se identifica con el acto mismo de la escritura, entendido como un proceso irreversible asumido por un autor-creador ${ }^{103}$. Así, mientras el tópico apela en una primera instancia al sacrificio ritual del sujeto a través del cual éste retorna al origen (acto compensador en que la muerte simbólica restaura el desorden creado por la muerte real), en una segunda resulta como negación de un sistema poético considerado amenazante $^{104}$.

\footnotetext{
${ }^{102}$ Cfr. Gil de Biedma (1992). Las composiciones «No volveré a ser joven» $\mathrm{y}$ «Después de la muerte de Jaime Gil de Biedma» son paradigmáticas de lo que decimos. Así, en la primera podemos leer: «Dejar huella quería / y marcharme entre aplausos / -envejecer, morir, eran tan sólo / las dimensiones del teatro. // Pero ha pasado el tiempo / y la verdad desagradable asoma: / envejecer, morir, / es el único argumento de la obra» (Gil de Biedma, 1992: 152). En la segunda: «El jardín y la casa cercana / donde pían los pájaros en las enredaderas, / una tarde de agosto, cuando va a oscurecer / y se tiene aún el libro en la mano, / eran, me acuerdo, símbolo tuyo de la muerte» (Gil de Biedma, 1992: 155).

${ }^{103}$ Cfr. Mas (1986: 36).

${ }^{104}$ Cfr. Valente (1980). En su primer libro, A modo de esperanza, los poemas «Serán ceniza», «Consiento» o «El corazón» establecen este tópico con un sentido de muerte ritual simbólica; pero en «Hoy igual a nunca», «Aniversario» $\mathrm{o}$ «Carta incompleta» aparece el acto negador del discurso poético. Ya en títulos posteriores, el poeta inserta el tópico dentro del conjunto simbólico que aglutina erotismo, sacrificio, poesía y amor como una particular forma de violencia indagadora. Así, en el último poema de Treinta y siete fragmentos (1971), el XXXVII, hallamos: «Supo, / después de mucho tiempo en la espera
} 
Sin embargo, es en el conjunto poético del 68 donde la resemantización del tópico se liga a una experiencia de lenguaje que conduce al vacío de la referencia y de la representación simbólica. La mayoría de estos poetas actualizan en sus textos el motivo romántico de una «muerte en vida de la obra», porque en ellos esta manifestación de la muerte se asocia al fracaso del discurso para hablar del mundo y de la propia memoria: la representación poética sólo refleja la opacidad de la palabra. La asunción de esta imposibilidad comporta actitudes de un particular desengaño ante el arte que, como construcción simbólica, ni logra ocultar la finitud humana con sus representaciones y simulacros, ni puede ser signo estable de permanencia. Esta generación asienta en la literatura española un poso filosófico existencial de un concluyente «saber que no», máxima cognoscitiva que acepta lo inexorable mediante numerosas formas que «van desde la frialdad notarial al relatar el drama humano hasta las digresiones frívolas en que se deslíe la densidad trágica» (Prieto de Paula, 1996: 120).

Un caso señalado lo constituye la poesía de Pere Gimferrer, quien concibe el poema como un ámbito para indagar acerca de las complejas relaciones entre la realidad y sus conflictivas transformaciones en arte. En este autor, la intertextualidad del cine o de la propia literatura es imprescindible en la formación de una perspectiva fragmentaria para abarcar una realidad múltiple. En La muerte en Beverly Hills (1967), extenso poema ordenado en ocho partes, el poeta utiliza una mezcolanza de imágenes extraídas de ámbitos diversos: del culturalismo a la naturaleza, de la mítica «pop» a escenas famosas de películas. Todo ello forma un cúmulo de impresiones desordenadas incapaces de ser discriminadas de aquellas otras procedentes de la realidad: la evocación del tópico mediante emblemáticos episodios cinematográficos y la identificación personal con la muerte del héroe, logran conectar de una manera ambigua la vida y el $\operatorname{arte}^{105}$. También la poesía de Leopoldo María Panero expresa de un modo radical la alienación de las rutinas de la clase media burguesa, y una exacerbada oposición al empleo del lenguaje para comunicar significados racionales y personales: la fragmentación de las voces poéticas y los diversos niveles de conciencia lingüística hacen que sus escritos presenten una textualización esquizofrénica de la realidad, organizada frecuentemente desde la muerte ${ }^{106}$.

metódica / de quien aguarda un día / el seco golpe del azar, / que sólo en su omisión o en su vacío / el último fragmento llegaría a existir» (Valente, 1980: 399).

${ }^{105}$ Cfr. Gimferrer (1988a). En el fragmento II leemos: «Ya conozco tus uñas pintadas de rojo, el óvalo hechicero / de tu cara, tu sonrisa pastosa y húmeda de nymphette, / esos vestidos negros, estas mallas, tus guantes hasta el / codo, el encaje en los pechos, / esta espalda que vibra y palpita como una columna de mercurio. / Cuando amanezca me encontrarán muerto y llamarán a Charlie Chan. [...]». O, en el fragmento VIII: «Las oficinas de los aeropuertos, con sus luces de clínica. / El paraíso, los labios pintados, las uñas pintadas, la sonrisa, las rubias platino, los escotes, el mar verde y oscuro. / Una espada en la helada tiniebla, un jazmín detenido en el tiempo. / Así llega, como un áncora descendiendo entre luminosos arrecifes, / la muerte» (Gimferrer, 1988a: 101-115).

${ }^{106}$ Sirva de ejemplo el poema «Pavane pour un enfant defunt», de Así se fundó Carnaby Street (1970): «Se diría que eres aún como siempre / que eres aún en la tierra un niño difunto. Se diría, se arriesga / el poema por alguien / 
Del mismo modo, este tópico articula en la poesía de Guillermo Carnero el sentido de una escritura que trata irónicamente la perdurabilidad del arte frente a la vida. Dibujo de la muerte (1967) situaría como núcleo del libro no sólo este conflicto entre el arte y su incapacidad para eternizar su experiencia en el lenguaje, sino la consideración misma del arte como una expresión lograda del destino humano. El poema «Ávila» confiere, en un juego irónico, valor redentor a los símbolos culturalistas que recorren el poema en oposición a la certeza de la muerte, pero los versos acaban por señalar su fracaso en su tarea de conceder perdurabilidad ${ }^{107}$. El poema desarrolla dos perspectivas contradictorias de la obra de arte: si, de un lado, la perfección del objeto artístico lo eleva por encima de la vida, de su carácter caduco y temporal, de otro, su misma contemplación revela su insuficiencia para asegurar perennidad. Por tanto, su apariencia bella es sólo un emblema que recuerda la finitud del hombre: de su contemplación se desprende una imperturbable consciencia de estar ante un espejo que refleja la muerte. Este poema marcaría la pauta temática del libro, al mostrar un conflicto existente entre la belleza perdurable del arte y la decadencia humana: un conflicto, dígase, que parece no resolverse a favor de una solución esteticista, y cuya indeterminación no privilegia ninguno de tales extremos significativos ${ }^{108}$. También el poema «Jardín inglés», de $E l$ sueño de Escipión (1971), insiste en esta resemantización del tópico vinculada a la reflexión sobre la escritura, ya que los múltiples motivos de lo yerto conviven con la precisión del artificio poético erigido en un ámbito frustrado que intenta preservar de la caducidad humana. En definitiva, el arte es una ficción que no resuelve el problema de la existencia, y la poesía constituye una expresión duradera, pero irreal, de la vida, debido a la insuficiencia de la palabra para reflejarla ${ }^{109}$.

\section{Bibliografía}

Agamben, Giorgio (1982): "El lenguaje y la muerte. Séptima jornada"; en CABO, Fernando (1999), pp. 105-126.

Aguirre, José M.. (1973): Antonio Machado, poeta simbolista, Madrid, Taurus.

Alda Tesán, J. M., ed. (1985): Jorge Manrique, Poesía, Madrid, Cátedra.

AZANCOT, Leopoldo (1971): “Don Carlos”, Litoral [homenaje a Ory], 19-20, p. 57-60.

como un disparo de pistola, / en la noche, en la noche sembrada / de ojos desiertos, de ojos solos / de monstruos. Todos nosotros somos / niños muertos, clavados en la balaustrada como por encanto / a la balaustrada frágil del balcón de la infancia, esperando / como sólo saben esperar los muertos. / Se diría que has muerto y eres alguien por fin, / un retrato en la pared de los muertos» (apud Talens, ed., 1992: 118-120).

107 «[P]ero yo sé que nada hay de ti entre tus libros, / en tus palabras, nada puede saberse, nada / puedes mostrar [...] / Por eso, entre el inmenso latido de la noche, / elevado entre un rumor de vides húmedas, es triste / no tener ni siquiera un puñado de palabras, un débil / recuerdo tibio, para aquí, en la noche, / imaginar que algún día podremos / inventarnos, que al fin hemos vivido» (apud López, ed., 1998: 97-100).

${ }^{108}$ Cfr. Debicki (1997: 209).

${ }^{109}$ Cfr. Lanz Rivera (1989: 96-103). 
BARTHES, Roland (1973): “¿Qué es la literatura?”, Nuevos ensayos críticos, Buenos Aires, Siglo XXI.

BAudelaire, Charles (1857): Las flores del mal, trad. de Manuel Neila, Madrid, Círculo de Lectores, 1985.

BAUDRILlARD, Jean (1980): El intercambio simbólico y la muerte, Venezuela, Monte Ávila.

Bertelloni, M. T. (1997): Epistemología de la creación poética, Madrid, Parteluz.

BLESA, Túa (1998a): Logofagias. Los trazos del silencio, Zaragoza, Tropelías. (1998b): "Confusa turba de discursos mudos", en CABO, Fernando, y Gullón, Germán, eds. (1998), pp. 135-158.

Bousoño, Carlos (1980): "Risa y razón en Guillermo Carnero", en Francisco Rico (ed.), Historia y crítica de la literatura española, vol. 8 (Época contemporánea, 1939-1980), Barcelona, Crítica, pp. 313-317.

(1984): Poesía poscontemporánea, Madrid, Júcar.

CABO, Fernando, ed. (1999): Teorías sobre la lírica, Madrid, Arco-Libros.

CABO, Fernando, y Gullón, Germán, eds. (1998): Teoría del poema: la enunciación lírica, Amsterdam / Atlanta, Rodopi.

CAÑAS, Dionisio (1989): “El sujeto poético postmoderno”, Ínsula, 512-513, pp. 52-53.

CARnERO, Guillermo (1983): "La corte de los poetas. Los últimos veinte años de poesía española en castellano", Revista de Occidente, 23, pp. 43-59.

CASTRO, Américo (1957): "Muerte y belleza. Un recuerdo a Jorge Manrique", en Hacia Cervantes, Madrid, Taurus, pp. 51-57

Combe, Dominique (1996): "La referencia desdoblada: el sujeto lírico entre la ficción y la autobiografía"; en CABO, Fernando, (1999), pp. 127-153.

Cuesta ABAD, José Manuel (1997): Las formas del sentido: estudios de poética y hermenéutica. Madrid, Universidad Autónoma de Madrid.

CURTIUS, Ernst Robert (1955): “Tópica de la consolación”, en Literatura europea y Edad Media latina, México, FCE, vol. I, pp. 122-127.

DeBICKI, Andrew P. (1987): Poesía del conocimiento. La generación española de 1956-1971, Madrid, Júcar.

(1997): Historia de la poesía española del siglo XX. Desde la Modernidad hasta el presente, Madrid, Gredos.

De CuenCA, Luis Alberto (1979-1980): "La generación del lenguaje”, Poesía, 5-6, pp. 245-251.

DE MAN, Paul (1971): Blindness and Insight, Nueva York, Oxford UP. (1984): The Rhetoric of Romanticism, Nueva York, Columbia UP.

DERRIDA, Jacques (1971): De la gramatología, México, Siglo XXI.

ECO, Umberto (1963): Obra abierta, Barcelona, Seix Barral. 
(1978): La estructura ausente. Introducción a la semiótica, Barcelona, Lumen.

FERNÁNDEZ, Luis Miguel (1994): "De la «poética de los muertos» al paisaje trascendente. Una aproximación a las relaciones entre Chateaubriand y Bécquer", Anales de Literatura Española, 10, pp. 81-100.

FERRARI, Marta (1996): “Un espejo fragmentado: la práctica metapoética de Guillermo Carnero", en SCARANO, Laura et al., Marcar la piel del agua. La autorreferencia en la poesía española contemporánea, Rosario (Argentina), Beatriz Viterbo, pp. 141-148.

FERrARI, Marta, et al. (1994): La voz diseminada. Hacia una teoría del sujeto en la poesía española, Buenos Aires, Biblos.

FERrATER, Juan (1968): "Linguiística y poética", en CABO, Fernando, (1999), pp. 155-173.

FRIEDRICH, Hugo (1959): Estructura de la lírica moderna. De Baudelaire a nuestros días, Barcelona, Seix Barral.

GARcíA, Miguel Ángel (2001): El veintisiete en Vanguardia. Hacia una lectura histórica de las poéticas moderna y contemporánea, Valencia, Pre-Textos.

García Berrio, Antonio (1994): Teoría de la literatura, Madrid, Cátedra, $2^{\mathrm{a}}$ ed. ampliada.

GARcía JAMBrinA, Luis (1992): “¿Poetas de los sesenta o poetas «descolgados»? (Notas para una nueva revisión)", Ínsula, 543, p. 8.

GEIST, Anthony L. (1980): La poética de la generación del 27 y las revistas literarias: de la vanguardia al compromiso (1918-1936), Barcelona, Guadarrama.

GIL DE BIEDMA, Jaime (1992): Las personas del verbo, Barcelona, Seix Barral.

GIMFERRER, Pere (1988a): Poemas 1962-1969, Madrid, Visor, 1988. (1988b): "Poética", en Pedro Provencio, ed. (1988), vol. II.

HAMBuRGER, Michael (1992): La verdad de la poesía. Tensiones en la poesía moderna: de Baudelaire a los años sesenta, México, FCE.

HASSAN, Ihab (1984): Paracriticisms, Urbana, University of Illinois.

HuIZINGA, Johan (1972): "La imagen de la muerte", en El otoño de la Edad Media, Madrid, Alianza, pp. 194-212.

ISER, Wolfgang (1976): El acto de leer, Madrid, Taurus, 1987.

JiMÉNEZ, Juan Ramón (1989): Antología poética, Madrid, Cátedra.

JiMÉNEZ, José Olivio (1972): "Estética del lujo y de la muerte: sobre Dibujo de la muerte de Guillermo Carnero", en Diez años de poesía española (1960-1970), Madrid, Ínsula, pp. 375-389.

(1985): "Identidad y palabra secreta: la poesía de Marcos Ricardo Barnatán", Ínsula, 466, pp. 17-18. 
KERMODE, Frank (1979): "El control institucional de la interpretación”, en Enric Sullà, ed., El canon literario, Madrid, Arco-Libros, 1998, pp. 91-112.

LANZ Rivera, Juan José (1989): "Rechazo del realismo y del surrealismo: por una concepción barroca y simbolista de la poesía de Guillermo Carnero", Zurgai (diciembre 1989), pp. 96-103.

- (1990): "Etapas y reflexión metapoética en la poesía castellana de Pere Gimferrer", Iberoamericana, 14, pp. 26-51.

(1994): La llama en el laberinto. Poesía y poética en la generación del 68, Mérida, Editora Regional de Extremadura.

- (2000): Introducción al estudio de la generación poética española de 1968. Elementos para la elaboración de un marco histórico-crítico en el período 1962-1977, Bilbao, Universidad del País Vasco.

Lida de MALKiel (1952): María Rosa, La idea de la Fama en la Edad Media castellana, México, FCE.

LóPEZ, Ignacio Javier, ed. (1998): Guillermo Carnero, Dibujo de la muerte. Obra poética, Madrid, Cátedra.

MALlarme, Stefan (1891): "Sur l'évolution littéraire", en Oeuvres complètes, París, Gallimard, 1945, pp. 866-872.

MARCEL, Raymond (1983): De Baudelaire al surrealismo, Madrid, FCE.

MAs, Miguel (1986): La escritura material de José Ángel Valente, Madrid, Hiperión.

Molinero, Miguel Ángel (1983): "Prólogo", en Agustín Delgado, De la diversidad (Poesía 1965-1980), Madrid, Hiperión.

Navajas, Gonzalo (1987): Teoría y práctica de la novela española posmoderna, Barcelona, Edicions del Mall.

PAZ, Octavio (1952): El laberinto de la soledad, México, FCE.

Paz Gago, José María (1999): La recepción del poema. Pragmática del texto poético, Oviedo, Universidad de Oviedo.

PÉREZ Firmat, Gustavo (1978): “Apuntes para un modelo de intertextualidad en la literatura", Romanic Review, 69, pp. 1-13.

PERLOFF, Marjorie (1981): The Poetics of Indeterminancy: Rimbaud to Cage, Princeton, Princeton UP.

Pozuelo Yvancos, José María (1988): Teoría del lenguaje poético, Madrid, Cátedra.

— (1994): "Pragmática, poesía y metapoesía en «El poeta» de V. Aleixandre", en CABO, Fernando (1999), pp. 41-75.

(1998): “Enunciación lírica?”, en CABO, Fernando, y Gullón, Germán, eds. (1998), pp. 41-75.

PRIETO DE PAUlA, Ángel L. (1991): La lira de Arión. De poesía y poetas españoles del siglo XX, Alicante, Universidad de Alicante. 
- (1993): 1939-1975: Antología de la poesía española, Alicante, Aguaclara.

- (1996): Musa del 68. Claves para una generación poética, Madrid, Hiperión.

Provencio, Pedro, ed. (1988): Poéticas españolas contemporáneas, 2 vols., Madrid, Hiperión.

RIFFATERre, Michel (1978), Sémiotique de la poésie, París, Seuil, 1982.

RoDRíGUEZ, Juan Carlos (1994): La norma literaria, Granada, Diputación.

RoiG DEL CAMPO, José A (1967): "La muerte en la poesía de Quevedo", Humanidades, XIX (46), pp. 79-101.

SÁncheZ TORRE, Leopoldo (1991): La poesía en el espejo del poema. La práctica metapoética en la poesía española del siglo XX, Oviedo, Universidad de Oviedo.

- (1989): "Metapoesía y conocimiento: la práctica novísima", Zurgai (diciembre 1989), pp. 24-29.

SEPÚlVEDA-PUlviRENTI, Emma (1990): Los límites del lenguaje: un acercamiento a la poética del silencio, Madrid, Torremozas.

Silver, Philip W. (1985): La casa de Anteo. Estudios de poética hispánica, Madrid, Taurus.

SCARANO, Laura (1991): "La poesía de Guillermo Carnero: una estética de la negatividad", Anales de la Literatura Española Contemporánea, núm. 16.3, pp. 321-335.

SCHMIDT, S. J. (1978), "La comunicación literaria", en MAYORAL, J. A. et al., Pragmática de la comunicación literaria, Madrid, Arco-Libros, 1987, pp. 194-212.

STIERLE, Karl (1997): “Lenguaje e identidad del poema. El ejemplo de Hölderlin”, en CABO, F. (1999), pp. 203-268.

TAlens, Jenaro (1980): Otra escena. Profanación(es), Madrid, Hiperión. (1981): “(Desde) la poesía de Antonio Martínez Sarrión”, en Antonio Martínez Sarrión, El centro inaccesible, Madrid, Hiperión.

—, ed. (1992): "Introducción” a Leopoldo María Panero, Agujero negro llamado Nevermore, Madrid, Cátedra, 1992.

Trabado Cabado, José Manuel (2002): La lectura lírica. Asedios pragmáticos a textos poéticos, León, Universidad de León.

VALENTE, José Ángel (1971): Las palabras de la tribu, Madrid, Siglo XXI. (1980): Punto cero. Poesía 1953-1978, Barcelona, Seix Barral.

Zavala, Iris M. (1965): "La muerte en la poesía de Quevedo. Tema del siglo XX", en La angustia y la búsqueda del hombre en la literatura, México, Universidad Veracruzana, pp. 41-60.

Zimmermann, Marie-Claire (1983): "Les jeux de la théorie et de la pratique dans la poésie espagnole actuelle (1965-1981)”, Les Langues Néo-Latines, 245, pp. 7-22. 